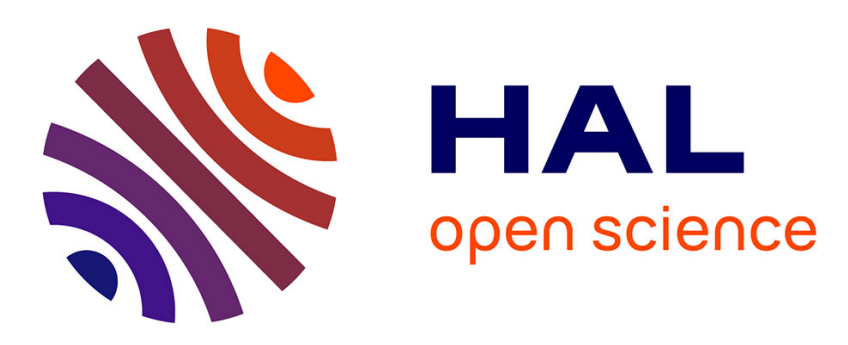

\title{
Radiogenic isotopes document the start of subduction in the Western Pacific
}

\author{
Hong-Yan Li, Rex N Taylor, Julie Prytulak, Maria Kirchenbaur, John W \\ Shervais, Jeffrey G Ryan, Marguerite Godard, Mark K Reagan, Julian A \\ Pearce
}

\section{To cite this version:}

Hong-Yan Li, Rex N Taylor, Julie Prytulak, Maria Kirchenbaur, John W Shervais, et al.. Radiogenic isotopes document the start of subduction in the Western Pacific. Earth and Planetary Science Letters, 2019, 518, pp.197-210. 10.1016/j.epsl.2019.04.041 . hal-02190200

\section{HAL Id: hal-02190200 \\ https://hal.umontpellier.fr/hal-02190200}

Submitted on 10 Nov 2020

HAL is a multi-disciplinary open access archive for the deposit and dissemination of scientific research documents, whether they are published or not. The documents may come from teaching and research institutions in France or abroad, or from public or private research centers.
L'archive ouverte pluridisciplinaire HAL, est destinée au dépôt et à la diffusion de documents scientifiques de niveau recherche, publiés ou non, émanant des établissements d'enseignement et de recherche français ou étrangers, des laboratoires publics ou privés. 


\title{
Radiogenic isotopes document the start of subduction in the Western Pacific
}

\author{
Hong-Yan Li ${ }^{a}$, Rex N. Taylor ${ }^{b}$, Julie Prytulak ${ }^{c, 1}$, Maria Kirchenbaur ${ }^{d}$, John W. Shervais ${ }^{e}$, \\ Jeffrey G. Ryan ${ }^{\mathrm{f}}$, Marguerite Godard ${ }^{\mathrm{g}}$, Mark K. Reagan ${ }^{\mathrm{h}}$, Julian A. Pearce ${ }^{\mathrm{i}, *}$
}

\author{
a State Key Laboratory of Isotope Geochemistry, Guangzhou Institute of Geochemistry, Chinese Academy of Sciences, Guangzhou 510640, PR China \\ b School of Ocean and Earth Science, University of Southampton, NOC, Southampton, SO14 3ZH, UK \\ c Department of Earth Science and Engineering, Imperial College London, London SW7 2AZ, UK \\ d Institut für Mineralogie, Universität zu Köln, Germany \\ e Department of Geology, Utah State University, Logan, UT, USA \\ ${ }^{\mathrm{f}}$ School of Geosciences, University of South Florida, Tampa, FL, USA \\ g Géosciences Montpellier, CNRS, Université de Montpellier, Montpellier, France \\ ${ }^{\mathrm{h}}$ Department of Earth and Environmental Sciences, University of Iowa, Iowa City, IA, USA \\ ${ }^{i}$ School of Earth and Ocean Sciences, Cardiff University, Cardiff CF10 3AT, UK
}

Keywords:

radiogenic isotopes

subduction initiation

forearc basalts

boninites

International Ocean Discovery Program

(IODP) Expedition 352

\begin{abstract}
A B S T R A C T
Subduction initiation is one of the least understood aspects of plate tectonics. In an effort to obtain the first in situ magmatic record of subduction initiation, the International Ocean Discovery Program Expedition 352 drilled at four sites in the inner trench wall of the Bonin Trench to recover $1.22 \mathrm{~km}$ of oceanic upper crust accreted within a few m.y. of subduction initiation. The two sites nearer to the trench (U1440 and U1441) yielded axial and off-axis fore-arc basalts (FAB), while those c. $15 \mathrm{~km}$ further from the trench (U1439 and U1442) yielded axial low-silica boninites and high-Mg andesites overlain by off-axis high-silica boninites. This study uses $\mathrm{Hf}-\mathrm{Nd}-\mathrm{Sr}-\mathrm{Pb}$ isotope analyses from c. 50 stratigraphically representative core samples to trace the evolution of the mantle source during the brief period of FABthrough-boninite magmatism immediately following subduction initiation. Results show that: 1) the FAB have high $\varepsilon \mathrm{Hf}$ relative to $\varepsilon \mathrm{Nd}$ and were derived from variably depleted mantle of 'Indian' provenance with no detectable subduction input; 2) the axial boninites follow mixing trends between a residual FAB mantle source and a subduction component derived from shallow (amphibolite facies) melting of oceanic crust of 'Pacific' provenance; and 3) the off-axis boninites define mixing trends between a hybrid mantle wedge (residual mantle + slab melt) and an additional subduction component with lower $\varepsilon$ Nd and higher ${ }^{207} \mathrm{~Pb} /{ }^{204} \mathrm{~Pb}$ that requires a significant contribution from pelagic sediment. This incoming of pelagic sediments may signify a change from an accretionary to non-accretionary margin as subduction evolves. The results thus indicate a rapidly evolving system in terms of geodynamics, magma genesis and crustal accretion immediately following subduction initiation.
\end{abstract}

\section{Introduction}

Unlike most types of plate tectonic process, regional-scale subduction initiation is not taking place at the present-day. In consequence, subduction initiation is one of the least understood aspects of plate tectonics. Much of our limited geological knowledge to date derives from the Izu-Bonin-Mariana (IBM) outer forearc, which carries a full record of magmatic and tectonic activity from

\footnotetext{
* Corresponding author.

E-mail address: pearceja@cf.ac.uk (J.A. Pearce).

1 Department of Earth Sciences, University of Durham, Durham DH1 3LE.
}

the start of subduction in the Eocene to the start of normal arc volcanism some 10 m.y. later (e.g. Ishizuka et al., 2011). It also hosts the type localities for the two rock types characteristic of subduction initiation and fore-arc terranes: forearc basalts (FAB), which are MORB-like tholeiitic basalts (Reagan et al., 2010), and boninites, which are distinctive high-Si, high-Mg, low-Ti volcanic rocks (e.g. Crawford, 1989).

The presence, and close association in space and time, of FAB and boninites during the birth of the IBM system have provided key supporting evidence for geodynamic models of subduction initiation. Notably, the presence of FAB supports the original Stern and Bloomer (1992) hypothesis that subduction initiation was immediately succeeded by subsidence and roll-back of the embryonic 


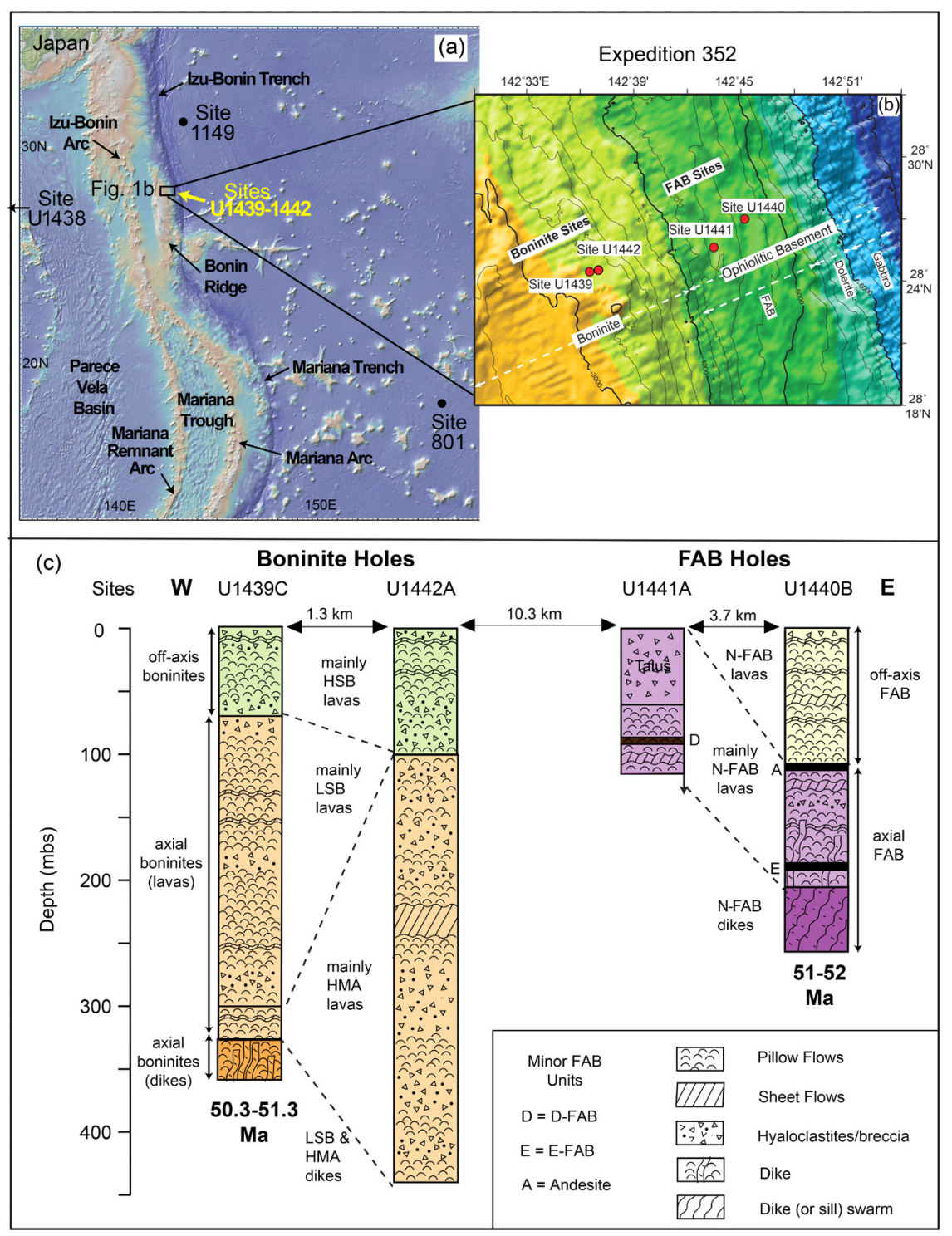

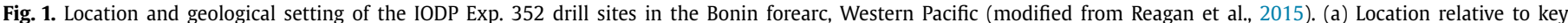

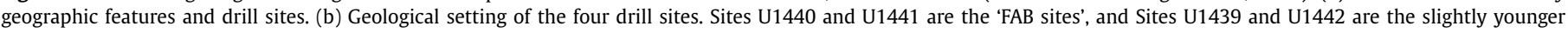

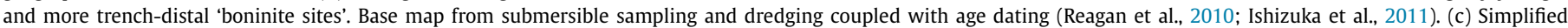

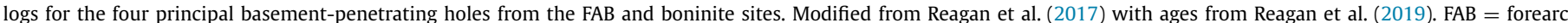

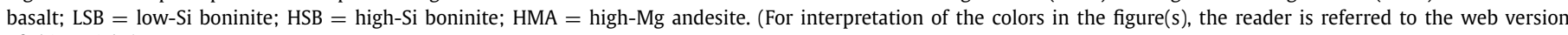
of this article.)

subducted slab resulting in an episode of near-trench extension or sea-floor spreading. In addition, the presence of boninites supports the need, in such a model, for a period of anomalous magmatism between initial subsidence and rollback and the establishment of the stable down-dip subduction required for normal island arc volcanism. The type of model proposed by Stern and Bloomer has since been supported by both ophiolite studies (e.g. Shervais, 2001; Dilek and Flower, 2003) and numerical experiments (e.g. Leng et al., 2012).

Despite much support for this general model, there is, however, much debate over the detail. For the starting conditions, Stern and Bloomer (1992) base their model on the reconstruction of Hussong and Uyeda (1981) and others in which subduction initiation began at a pure strike-slip, transform plate boundary, a setting that continues to be supported by tectonic reconstructions (e.g. Wu et al., 2016). However, Casey and Dewey (1984) argue for a transtensional boundary (a 'leaky' transform fault), which, if correct, may have led to episodes of ridge subduction follow- ing subduction initiation. Loci not involving a transform fault have also been proposed. These include a thermal anomaly in the mantle (Macpherson and Hall, 2001), the edge of an oceanic plateau (Niu et al., 2003) and a Mesozoic continental margin (Ishizuka et al., 2018).

Moreover, although the concept of slab roll-back as the cause of spreading, and hence the mechanism for FAB genesis, is supported by numerical models, it still requires ground-truthing. To do this, and to constrain better the pre-subduction tectonic setting, one of the optimal approaches is to establish the extent, stratigraphy and genesis of the volcanic rocks erupted immediately following subduction initiation. Because much of this evidence is sedimentcovered, drilling is needed. Thus, in 2014, IODP Expedition 352 to the Bonin forearc had the objective of documenting the changing nature and composition of the crust formed immediately after subduction initiation (Reagan et al., 2015). Here, we present the first radiogenic isotope ( $\mathrm{Hf}-\mathrm{Nd}-\mathrm{Sr}-\mathrm{Pb}$ ) data from the Expedition, and use these data to 1) establish the evolution of mantle sources and 
Table 1

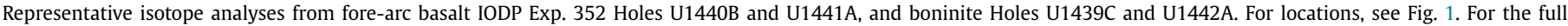

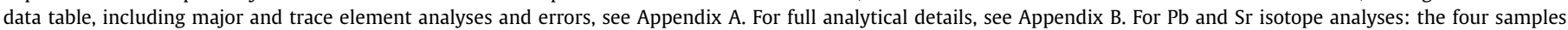

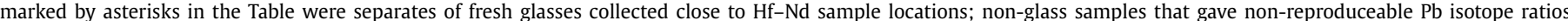

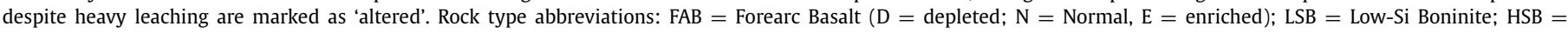
High-Si Boninite; HMA = High-Mg Andesite. All samples are lavas except U1440B Unit 15 and U1439C Unit 10, both of which are sheeted intrusions (superscript D).

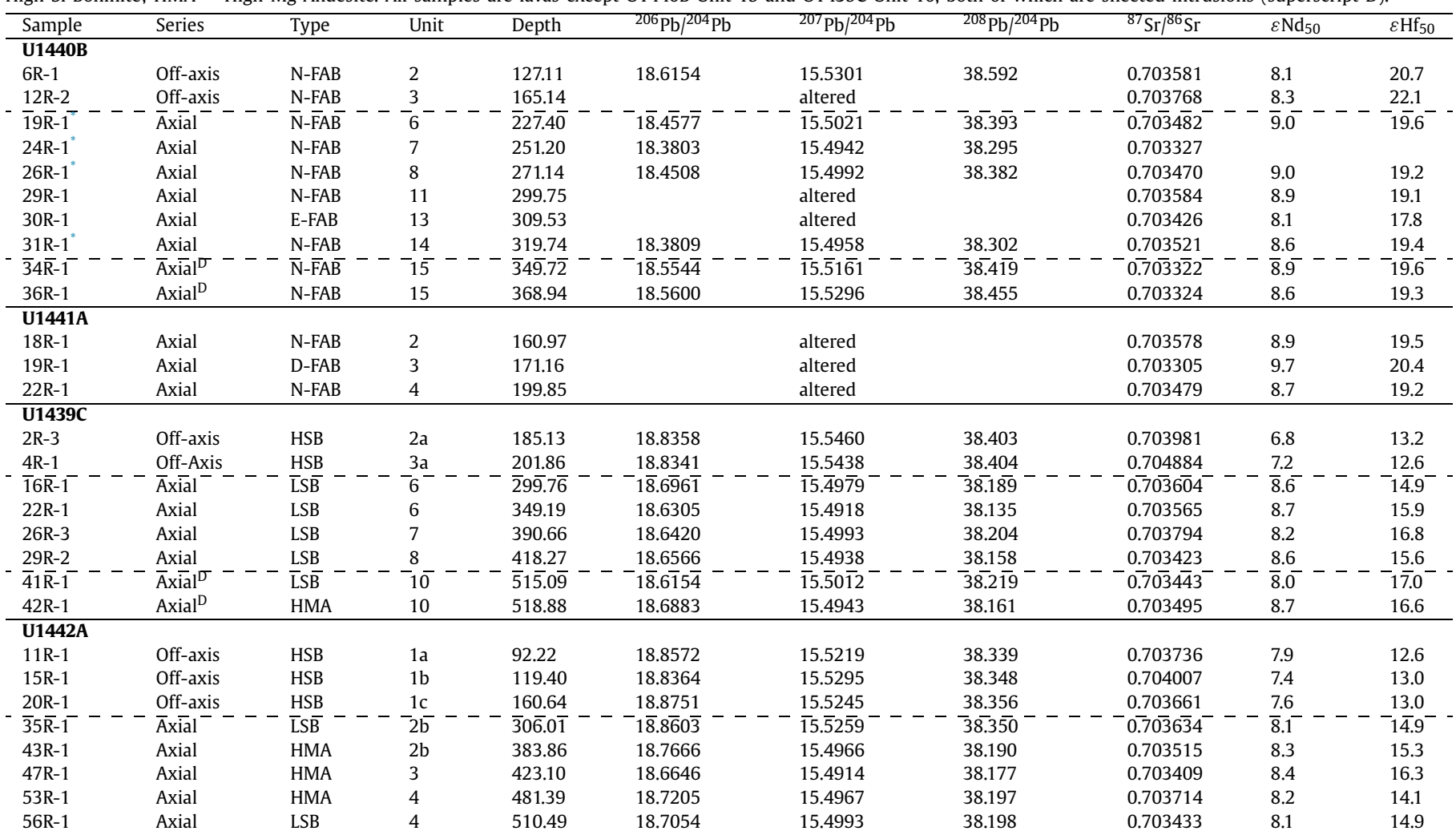

Glass separates used for $\mathrm{Pb}$ and $\mathrm{Sr}$ isotope analyses (except 31R-1: $\mathrm{Pb}$ only).

slab fluxes following subduction initiation and 2) use the resulting information to test, and develop new, hypotheses for the plate configurations and driving forces involved.

\section{Materials}

IODP Expedition 352 drilled at four sediment-covered sites between the ophiolitic sequence exposed in the inner trench wall in the east and the Bonin Ridge embryonic volcanic arc in the west (Fig. 1a-b). These subdivide into two deeper, more trench-proximal sites (U1440 and U1441: the 'FAB sites') and two shallower, trenchdistal sites (U1439 and U1442: the 'boninite sites'). Representative basement samples taken on-board the drilling ship from each of the petrologic units defined and described at these four sites (Reagan et al., 2015) form the basis for this isotope study.

Fig. 1c summarizes the stratigraphies for the holes with the deepest penetration, namely U1440B, U1441A, U1439C, and U1442A. All four recovered lavas, but one of the FAB holes (U1440B) and one of the boninite holes (U1439C) also rooted in sheeted intrusions (Reagan et al., 2015). The probable explanation is that upper oceanic crust was penetrated at both FAB and boninite sites, the former representing crust in the more trenchproximal location. Lava sequences at FAB Site U1440 and boninite Sites U1439 and U1442 have been divided into lower and upper units, each with a number of sub-units. In both FAB and boninite sites, the lower units compositionally match the underlying dikes and henceforth will be termed 'axial', while the upper units are compositionally distinct and will be termed 'off-axis'.

According to bulk rock $\mathrm{Ar}-\mathrm{Ar}$, and CA-TIMS zircon U-Pb, dating (Reagan et al., 2019), the FAB and boninites in this paper formed from an intermediate-rate, sea-floor spreading event that took place between approximately 52 and 50 Ma immediately following subduction initiation (Fig. 1c). The Bonin Ridge boninites and their differentiates subsequently erupted onto this oceanic crust between about 50 and $44 \mathrm{Ma}$ to form an embryonic arc, followed by normal tholeiitic and calc-alkaline arc magmatism (e.g. Cosca et al., 1998; Ishizuka et al., 2011).

In terms of rock type, the FAB are tholeiites and resemble MORB in all but setting and the greater degree of depletion of their mantle source. Shervais et al. (2019) subdivide axial- and off-axis FAB into a main, 'normal' group entitled N-FAB, less common depleted and enriched groups respectively entitled D-FAB and E-FAB, as well as primitive variants of these not distinguished here. The axial boninites are predominantly made up of low-Si boninites accompanied by their fractionation products, high-Mg andesites (HMA), while off-axis boninites are primarily made up of high-Si boninites (Reagan et al., 2015, 2017).

The preliminary model of Reagan et al. (2017) produces the FAB by decompression melting with little to no slab flux. Melting of an extremely depleted (harzburgitic) mantle flushed with fluids and/or melts from subducted sediments and oceanic crust then generated boninites. Shervais et al. (2019) refine the petrogenesis of the $\mathrm{FAB}$, providing evidence that their mantle source had higher potential temperatures than normal MORB but was more depleted due to an episode of prior, garnet-facies depletion.

\section{Methods}

Table 1 provides a subset of the data used in the geochemical plots, and the text below provides a brief summary of analytical 


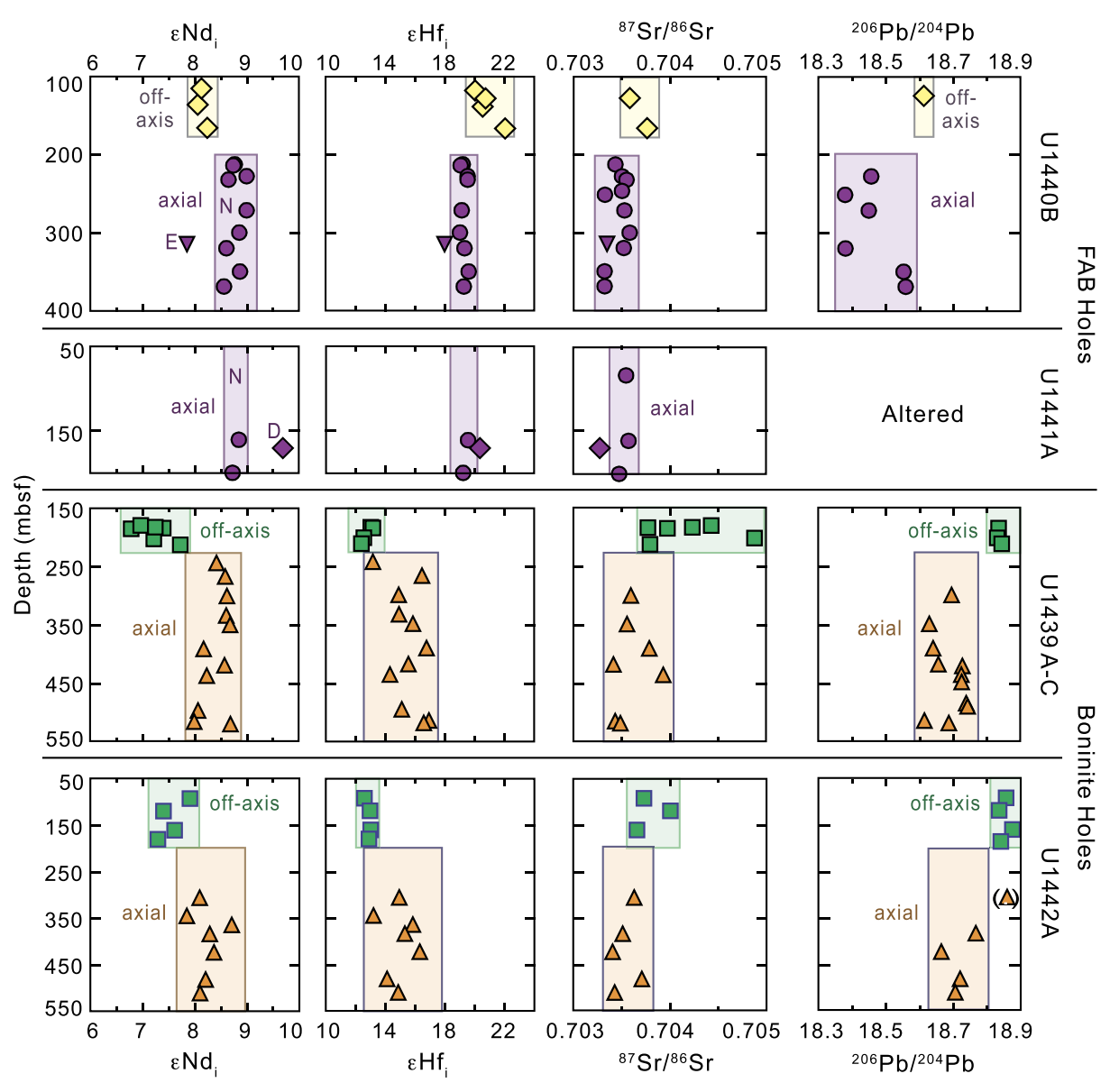

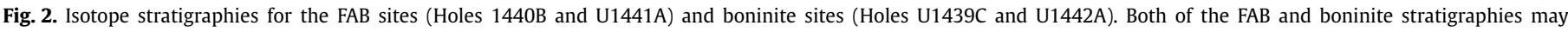

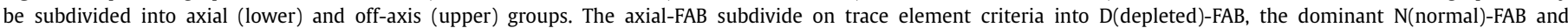

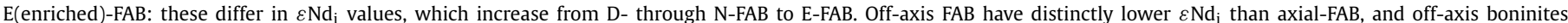

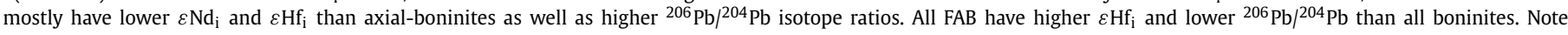

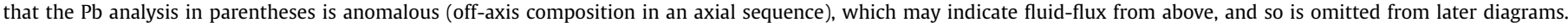
mbsf $=$ meters below sea-floor.

methods and quality controls. Appendix A contains sample locations and the full element and isotope dataset, and Appendix B gives full analytical detail.

\subsection{Preparation procedure}

Following crushing and agate milling, we analyzed these samples for major elements by XRF at Utah State University and trace elements by ICP-MS at Guizhou Tongwei Analytical Technology Co. Ltd. (Appendix B, Section 2). We heavily leached altered samples for analysis of isotopes of the alteration-mobile elements $\mathrm{Sr}$ and $\mathrm{Pb}$ (see Appendix B, Sections 3.3 and 5 for leaching procedures), but some analyses retained evidence of metasomatism, with $\mathrm{Pb}$ isotopes in FAB particularly affected. In such cases, if there was fresh glass or rock nearby, we reanalyzed $\mathrm{Pb}$ isotopes using the fresh material.

\subsection{Analytical methods}

We analyzed Hf isotope ratios at the Guangzhou Institute of Geochemistry, Chinese Academy of Sciences (GIGCAS) on a Neptune MC-ICPMS (Appendix B, Section 3). We took particular care to check for complete sample dissolution and hence avoid the potential problem of small, residual zircons (Appendix B: Section 7 and Table B.5). We report the $\mathrm{Hf}$ isotopic ratios relative to a ${ }^{176} \mathrm{Hf} /{ }^{177} \mathrm{Hf}$ ratio of 0.282189 for JMC14374 (corresponding to a value for JMC475 of 0.282158 ).
We also carried out neodymium isotope ratio analyses at GIGCAS on the Neptune MC-ICPMS (Appendix B, Section 3). We report the $\mathrm{Nd}$ isotopic ratios relative to ${ }^{143} \mathrm{Nd} /{ }^{144} \mathrm{Nd}$ of JNdi-1 = 0.512115 . We carried out further Nd isotope analyses in the MAGIC laboratories at Imperial College London with a Nu Instruments $\mathrm{HR}$ MC-ICPMS, also using neodymium standard, JNdi (Appendix B, Section 4). Analyses of USGS reference materials, BCR-2, BIR1a and BHVO-2, run as unknowns demonstrate excellent agreement both between the two laboratories and with accepted values (Appendix B, Table B.3). We determined $\mathrm{Sr}$ isotope ratios at both GIGCAS and the MAGIC using a Thermo Finnigan Triton thermal ionization mass spectrometer (TIMS) (Appendix B, Sections 3 and 4). Both laboratories report the $\mathrm{Sr}$ isotopic ratios relative to ${ }^{87} \mathrm{Sr} /{ }^{86} \mathrm{Sr}$ of NBS-987 $=0.710248$. Appendix B, Table B.2 gives international standard data obtained by the two laboratories.

We measured $\mathrm{Pb}$ isotope ratios on a Thermo Neptune MC-ICPMS at the University of Southampton UK, using a double spike to correct for instrumental mass fractionation (Appendix B, Section 5). Procedural blanks range between 30-95 pg Pb. NBS SRM 981 values achieved during the measurement period were ${ }^{206} \mathrm{~Pb} /{ }^{204} \mathrm{~Pb}$ $=16.9404 \pm 32,{ }^{207} \mathrm{~Pb} /{ }^{204} \mathrm{~Pb}=15.4969 \pm 32$ and ${ }^{208} \mathrm{~Pb} /{ }^{204} \mathrm{~Pb}=$ $36.7149 \pm 90$ (2s.d.; $n=44$ ). Propagated uncertainties for combined natural sample and spiked sample analyses were always less than the reproducibility $2 \sigma$ of NBS SRM 981.

Several diagrams in this paper combine our data with published data from other laboratories. Only Nd isotopes exhibited significant inter-laboratory variation. All data used in this paper have 
thus been normalized to ${ }^{143} \mathrm{Nd} /{ }^{144} \mathrm{Nd}$ of 0.511858 for the La Jolla standard, which is equivalent to the JNdi value of 0.512115 . We provide checks for internal consistency of these various data sets in Appendix B, Section 6. In the text that follows, we describe and explain the principal isotopic features under 'Results' and the more detailed isotopic component modeling under 'Interpretations'.

\section{Results}

\subsection{Isotope stratigraphy}

Fig. 2 gives the isotope stratigraphies for the four principal Exp. 352 holes. Off-axis FAB from U1440B have distinctively high $\varepsilon \mathrm{Hf}_{\mathrm{i}}$, low $\varepsilon \mathrm{Nd}_{\mathrm{i}}$ and high ${ }^{206} \mathrm{~Pb} /{ }^{204} \mathrm{~Pb}$. The axial-FAB (both lavas and dikes) are predominantly homogenous N-FAB compositions. Exceptions are the single analyzed sample of E-FAB, which has distinctly lower $\varepsilon \mathrm{Nd}_{\mathrm{i}}$ and slightly lower $\varepsilon \mathrm{Hf}_{\mathrm{i}}$, and the single analyzed sample of D-FAB, which has distinctly higher $\varepsilon \mathrm{Nd}_{\mathrm{i}}$ and slightly higher $\varepsilon \mathrm{Hf}_{\mathrm{i}}$. There is no significant difference between the axial N-FAB compositions from the two FAB holes.

Off-axis boninites have lower $\varepsilon \mathrm{Nd}_{\mathrm{i}}$ and lower or similar $\varepsilon \mathrm{Hf}_{\mathrm{i}}$ compared to axial-boninites, but higher or similar $\mathrm{Sr}$ and $\mathrm{Pb}$ isotope ratios. The axial-boninites are more variable than the axialFAB, likely reflecting their more complex genesis, which includes magma mingling (Reagan et al., 2015). There is no significant compositional difference between the off-axis boninites from the two holes, but there are small differences between axial-boninites (e.g. lower average ${ }^{206} \mathrm{~Pb} /{ }^{204} \mathrm{~Pb}$ and higher average $\varepsilon \mathrm{Nd}_{\mathrm{i}}$ in Hole $\mathrm{U} 1442 \mathrm{~A}$ ). Compared to the $\mathrm{FAB}$, all boninites have lower $\varepsilon \mathrm{Hf}_{\mathrm{i}}$ and higher ${ }^{206} \mathrm{~Pb} /{ }^{204} \mathrm{~Pb}$.

\subsection{Principal $\mathrm{Hf}, \mathrm{Nd}$, Sr and $\mathrm{Pb}$ element characteristics}

Fig. 3 depicts chondrite-normalized REE patterns extended to include $\mathrm{Pb}, \mathrm{Sr}$ and $\mathrm{Hf}$ in positions that maintain the order of incompatibility during melting of the upper mantle. Appendix A provides the full data set used for these patterns and for the means and standard deviations reported below. It also provides values for other petrogenetically significant trace elements.

For the FAB sites, mantle sources were variably depleted, as reflected in the variable slopes of the REE patterns in Fig. 3a. Of the axial-FAB, the E-FAB sample has the least LREE-depletion $(\mathrm{Ce} / \mathrm{Yb}$ $=2.46)$ and $\mathrm{D}-\mathrm{FAB}(\mathrm{Ce} / \mathrm{Yb}=0.96)$ the greatest. The axial N-FAB have intermediate levels of depletion $(\mathrm{Ce} / \mathrm{Yb}=1.50 \pm 0.13[1 \sigma])$ as do off-axis N-FAB $(\mathrm{Ce} / \mathrm{Yb}=1.63 \pm 0.05[1 \sigma])$. However, all the FAB are significantly more depleted than average N-MORB ( $\mathrm{Ce} / \mathrm{Yb}$ $=3.8 \pm 0.2[1 \sigma]$ and $\mathrm{D}-\mathrm{MORB}((\mathrm{Ce} / \mathrm{Yb}=3.0 \pm 0.2[1 \sigma])$ (data of Gale et al., 2013). Strontium and $\mathrm{Pb}$ show no selective element enrichments that might indicate a subduction component, provided the patterns are restricted to glass and the least-altered rocks.

For the boninite sites (Fig. 3b-c), all samples are significantly enriched in $\mathrm{Sr}$ and $\mathrm{Pb}$ relative to the surrounding REE, a characteristic of all arc-related lavas. Unlike most arc lavas, however, they exhibit pronounced positive Hf anomalies, features commonly associated with subduction initiation (e.g. Hickey-Vargas, 1989; Pearce et al., 1999). Their low concentrations of the subductionimmobile HREE indicate very depleted mantle sources, significantly more depleted than FAB sources. Their LREE enrichments $\mathrm{Ce} / \mathrm{Yb}$ $=3.05 \pm 0.44[1 \sigma]$ ) are, however, greater than most FAB, so requiring modification of this depleted mantle by a LREE-enriched subduction component. Thus Nd must have been subductionmobile during boninite genesis. Relative to $\mathrm{Sr}$, $\mathrm{Pb}$ and $\mathrm{Hf}$, however, chondrite-normalized $\mathrm{Nd}$ concentrations are low, and hence the mobility of Nd during subduction must also have been comparatively low.

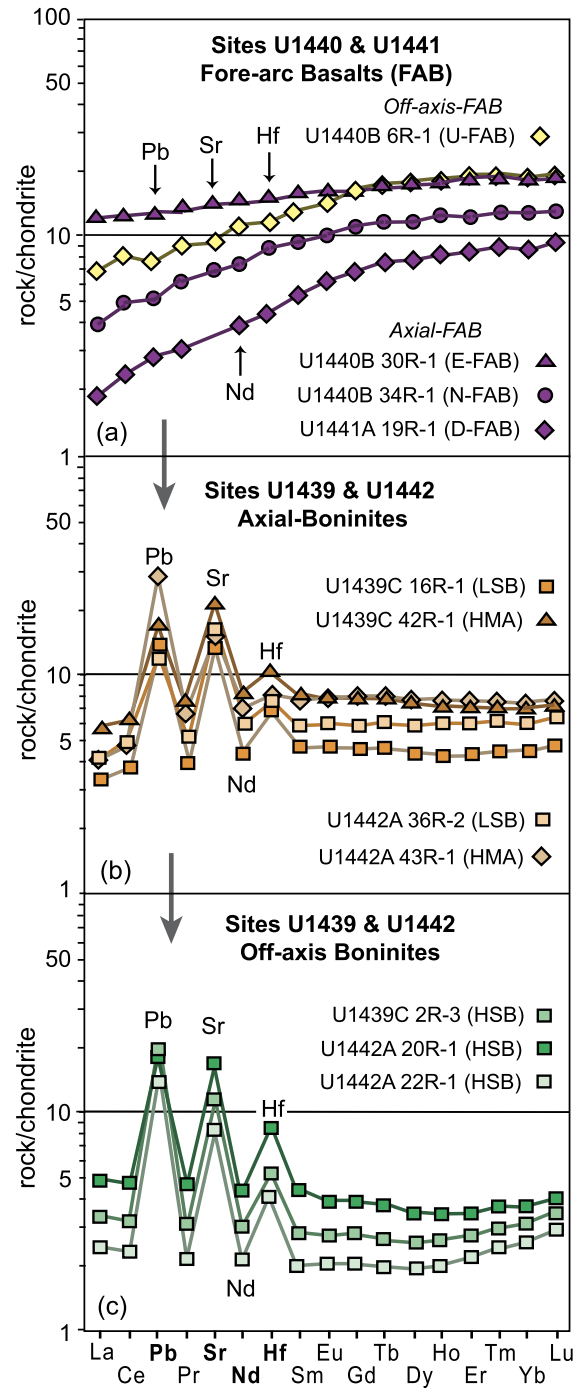

Fig. 3. Extended chondrite-normalized REE plots highlighting the changes in the radiogenic daughter isotope elements, $\mathrm{Pb}, \mathrm{Sr}$, $\mathrm{Nd}$ and $\mathrm{Hf}$ during the evolution from (a) axial- and off-axis FAB through (b) axial-boninites to (c) off-axis boninites. Note the absence of significant subduction-related anomalies in the FAB (the alterationrelated $\mathrm{Sr}$ anomaly in the D-FAB sample has been omitted), in contrast to the positive $\mathrm{Pb}, \mathrm{Sr}$ and $\mathrm{Hf}$ anomalies in the boninites. Note also that the LREE (and hence $\mathrm{Nd}$ ) progressively increase from $\mathrm{FAB}$ through axial boninite to off-axis boninite, as seen in the trend from LREE-depleted to slight LREE enrichment. Chondritenormalizing factors are from Sun and McDonough (1989), with the $\mathrm{Pb}$ value amended to remove the metallic component of the chondrite. For full elemental analyses, see Appendix A.

The difference between axial-boninites (Fig. 3b) and off-axis boninites (Fig. 3c) is less obvious than that between FAB and boninites. Primarily, the off-axis boninites have the larger $\mathrm{Pb}, \mathrm{Sr}$ and $\mathrm{Hf}$ peaks, lower and variable concentrations of the HREE for a given $\mathrm{MgO}$ content, and slight LREE enrichment $(\mathrm{Ce} / \mathrm{Yb}=$ $3.82 \pm 1.23[1 \sigma])$ rather than depletion. These features indicate that the off-axis boninites likely experienced greater degree of mantle depletion and a greater contribution from a subduction component containing all daughter elements ( $\mathrm{Pb}, \mathrm{Sr}, \mathrm{Hf}$ and $\mathrm{Nd})$.

\subsection{Principal $\mathrm{Sr}, \mathrm{Nd}, \mathrm{Hf}, \mathrm{Pb}$ isotope ratio covariations}

Fig. 4 summarizes the radiogenic isotope evolution from 1) axial-FAB to off-axis $F A B$ which defines the ambient mantle before subduction and then 2) from FAB to axial-boninite which defines the first stage of subduction and finally 3 ) from axial-boninite to 


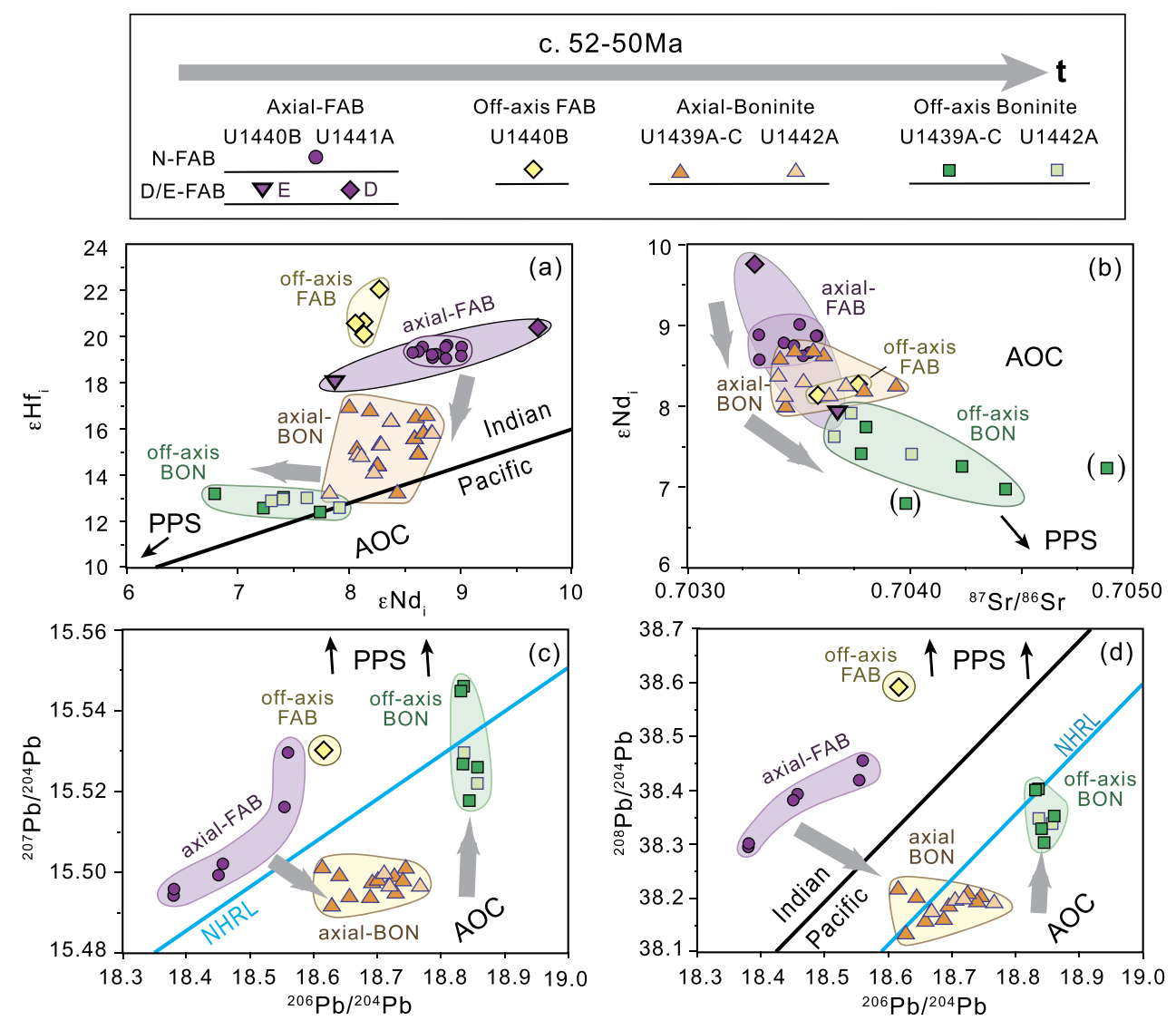

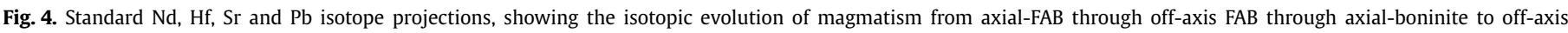

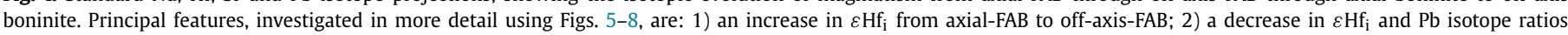

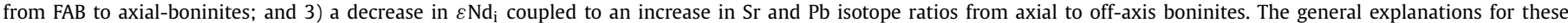

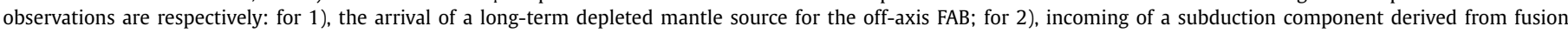

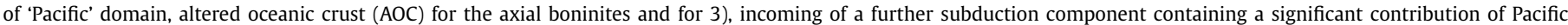
Pelagic Sediment (PPS) for the off-axis boninites. This is a remarkable variation for such small differences in space and time.

off-axis boninite which defines the beginning of the embryonic arc.

For 1), both the $\varepsilon \mathrm{Hf}-\varepsilon \mathrm{Nd}$ plot (Fig. 4a) and the ${ }^{208} \mathrm{~Pb} /{ }^{204} \mathrm{~Pb}-$ ${ }^{206} \mathrm{~Pb} /{ }^{204} \mathrm{~Pb}$ plot (Fig. 4d) are effective discriminants between the 'Pacific' and 'Indian' mantle source domains. On these plots, all FAB clearly plot well within the 'Indian' domain, a well-known characteristic of all basalts erupted within the Philippine Sea Plate (e.g. Hickey-Vargas, 1998).

For 2), the key characteristic is the decrease in $\varepsilon \mathrm{Hf}$ and ${ }^{208} \mathrm{~Pb} /{ }^{204} \mathrm{~Pb}$ from all FAB to axial-boninite. These features have already been identified in rocks from the nearby Bonin Ridge and attributed to the interaction of melt of 'Pacific' provenance from the newly-subducting Pacific Plate with overlying ambient mantle of 'Indian' provenance (Pearce et al., 1992; Li et al., 2013).

For 3 ), the key characteristic is the subsequent decrease in $\varepsilon \mathrm{Nd}$ accompanied by an increase in $\mathrm{Sr}$ and $\mathrm{Pb}$ isotope ratios from axial to off-axis boninites. This indicates the incoming of a further subduction component containing a significant contribution from Pacific Pelagic Sediment (PPS).

Fig. 4 thus highlights a remarkable variation over such a small range in space (c. $15 \mathrm{~km}$ : Fig. 1) and time ( $<2$ m.y.: Reagan et al., 2019), and perhaps holds the key to understanding the complex and rapid evolution of ophiolite complexes believed to have a subduction initiation origin. In the Sections that follow, we interpret the trends in Fig. 4 in more detail in an attempt to establish how they may take place in the context of Western Pacific subduction initiation.

\section{Interpretations}

\subsection{Characterizing the mantle source using $\varepsilon H f-\varepsilon N d$ covariations}

Applying the $\varepsilon \mathrm{Hf}-\varepsilon \mathrm{Nd}$ projection (Fig. $4 \mathrm{a}$ ) to FAB is a useful way to understand the nature and provenance of the ambient mantle at the start of subduction. Fig. 5a depicts MORB and OIB from the Western Pacific region. Our reference line is the Indian-Pacific mantle domain boundary (Pearce et al., 1999). This boundary has the equation $\varepsilon \mathrm{Hf}=\varepsilon \mathrm{Nd}^{*} 1.6$ and hence is almost parallel to, but displaced by c. 1.25 epsilon units from, the principal axis of dispersion of the global terrestrial array $\left(\varepsilon \mathrm{Hf}=\varepsilon \mathrm{Nd}^{*} 1.59+1.26\right)$ of Chauvel et al. (2009). The boundary also bisects the type PacificIndian mantle domain boundary from the Australian-Antarctic Discordance (AAD), a long distance further to the south-east (Kempton et al., 2002).

As many authors have noted, individual lava suites commonly form arrays (termed 'ambient mantle arrays' by Woodhead et al., 2012), which typically run sub-parallel to the Pacific-Indian boundary and global terrestrial array. Behind the trench, the most relevant ambient array is that of the Philippine Sea (Fig. 5a), which began spreading at about the time of subduction initiation and continued through the evolution of the Bonin Ridge embryonic arc. Its ambient array lies well within the 'Indian' domain.

In Fig. 5b, the axial-FAB plot in the upper 50-90 percentile of the Philippine Sea MORB-OIB array. They form an ambient FAB mantle array, which extends from E-FAB, through N-FAB to D$F A B$ and runs sub-parallel to other ambient mantle arrays within 

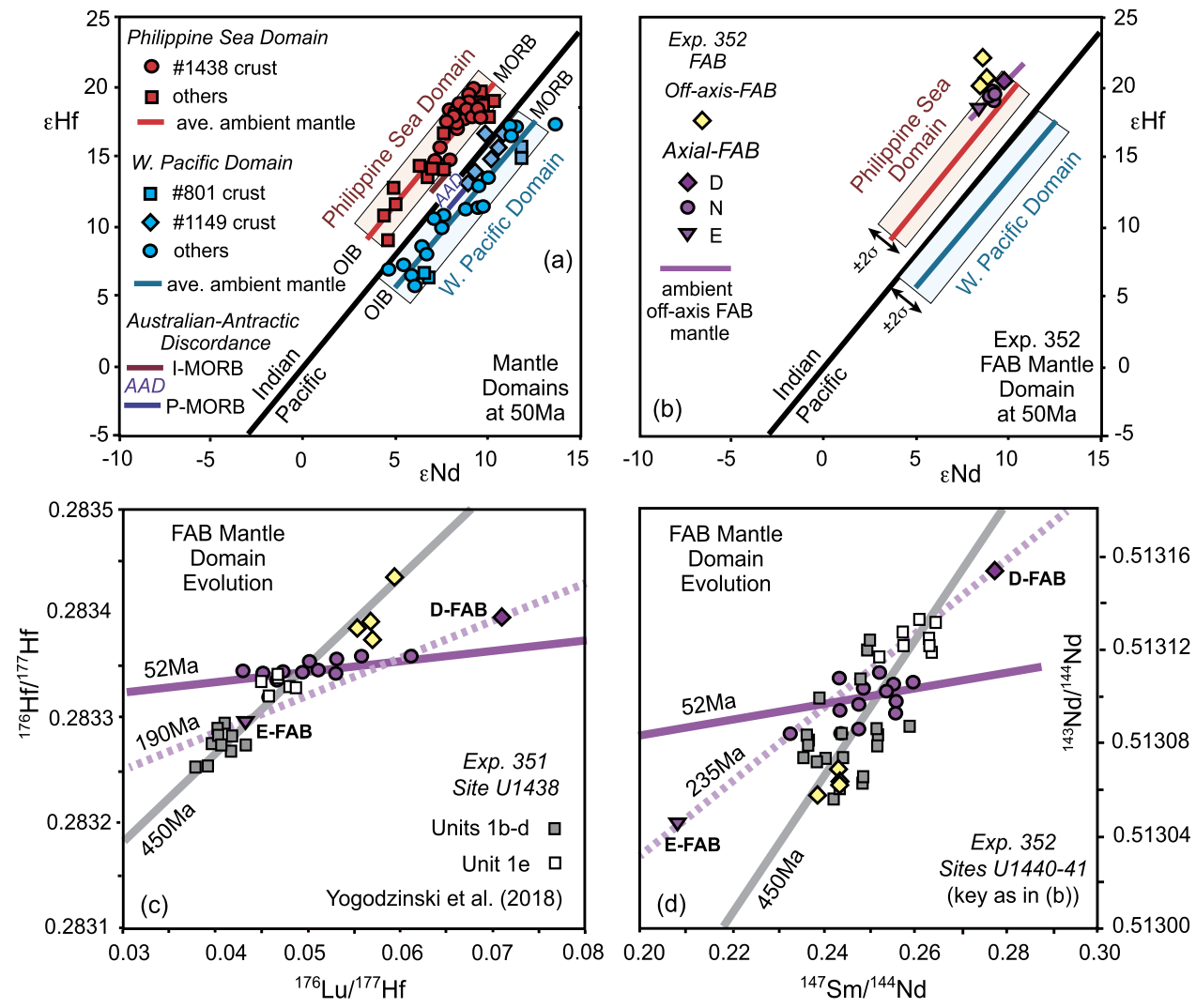

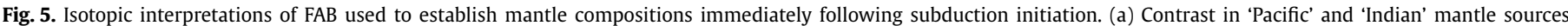

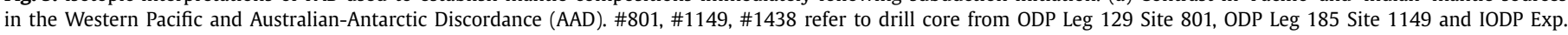

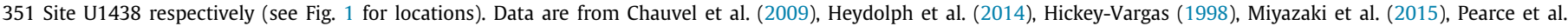

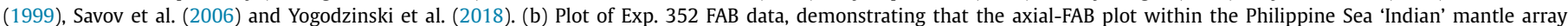

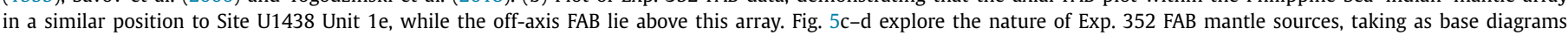

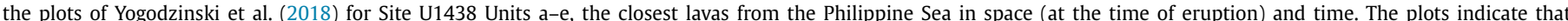

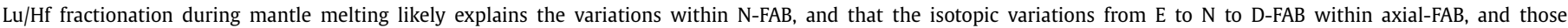

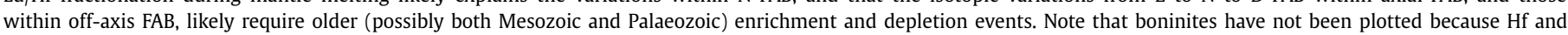

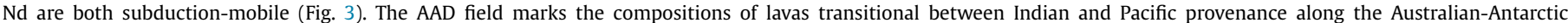
Ridge.

the Philippine Sea Plate. In contrast, the off-axis FAB form a nearvertical trend, which extends to $\varepsilon \mathrm{Hf}-\varepsilon \mathrm{Nd}$ values above the Philippine Sea array.

'Indian' characteristics, such as those exhibited by Exp. 352 FAB, have been attributed to mantle depletion during a partial melting event in garnet facies (as garnet fractionates Lu from Hf, but not $\mathrm{Sm}$ from $\mathrm{Nd}$ ) perhaps coupled with enrichment by a $\mathrm{Nd}-$ rich, Hf-poor subduction component (e.g. Kempton et al., 2002; Janney et al., 2005; Salters et al., 2011). This interpretation supports the hypothesis of Gurnis et al. (1998) that the 'Indian' domain province contains relics of subduction-modified, depleted lithosphere from a long history of sub-Gondwana subduction.

Yogodzinski et al. (2018) explored further the evolution of the mantle beneath the Philippine Sea Plate at about the time of subduction initiation by focusing on the 50-49 Ma basaltic basement at Site U1438. They used plots of ${ }^{176} \mathrm{Hf} /{ }^{177} \mathrm{Hf} \mathrm{v} \mathrm{Lu} / \mathrm{Hf}$ and ${ }^{143} \mathrm{Nd} /{ }^{144} \mathrm{Nd} v \mathrm{Sm} / \mathrm{Nd}$ to demonstrate that the mantle source experienced a long history of depletion, which includes a significant melt extraction event in the 400-500 Ma time window.

On their base diagram (Fig. $5 c-d$ ), we note that our main N-FAB magmas extend along a 52 Ma errorchron in Fig. 5c, indicating fractionation of $\mathrm{Lu} / \mathrm{Hf}$ during the melting event from which they formed. The D-FAB and E-FAB form two-point $195 \mathrm{Ma}$ and $235 \mathrm{Ma}$ errorchrons for the Lu-Hf and Sm-Nd systems respectively, a potentially significant observation but one requiring further analyses. The mean N-FAB composition and the off-axis FAB plot close to the Palaeozoic errorchrons plotted by Yogodzinski et al. (2018) for
IODP Site U1438: the combined basalt dataset from Sites U1438 and U1439-1442 gives similar $450 \mathrm{Ma}$ errorchrons on both diagrams (Fig. 5c-d), though with considerable scatter. Overall, therefore, our isotope data support the concept of Yogodzinski et al. (2018) and Shervais et al. (2019) that subduction initiated within a mantle domain that had already experienced one or more ancient depletion events, though more work is needed to ascertain precise ages and details. In any event, this mantle domain provides the mantle wedge end-member needed to explain the compositions of the subsequent subduction events.

\subsection{Characterizing the subduction component using isotope-element ratio covariations}

Plots of the form $\varepsilon \mathrm{Hf}_{\mathrm{i}}-\mathrm{x} / \mathrm{Hf}$ are particularly effective at interpreting Hf anomalies on the extended REE diagram (Fig. $3 b-c$ ) in terms of subduction components, as any mixing lines are then linear and so easier to interpret (e.g. Barry et al., 2006).

In Fig. 6a, $x=\mathrm{Sm}$, chosen because $\mathrm{Sm}$ is closest to $\mathrm{Hf}$ in its bulk partition coefficient during mantle melting and fractional crystallization. The axial-FAB data plot at the upper (MORB) end of the ambient Philippine Sea array, while the off-axis FAB lie on an extension of this array. As can be seen in all four diagrams (Fig. 6a-d), an average axial-FAB composition is the optimum choice for the isotopic mantle end-member for the subsequent generation of boninites. Being a boninite source, this end-member is depleted in incompatible elements compared to the FAB mantle 

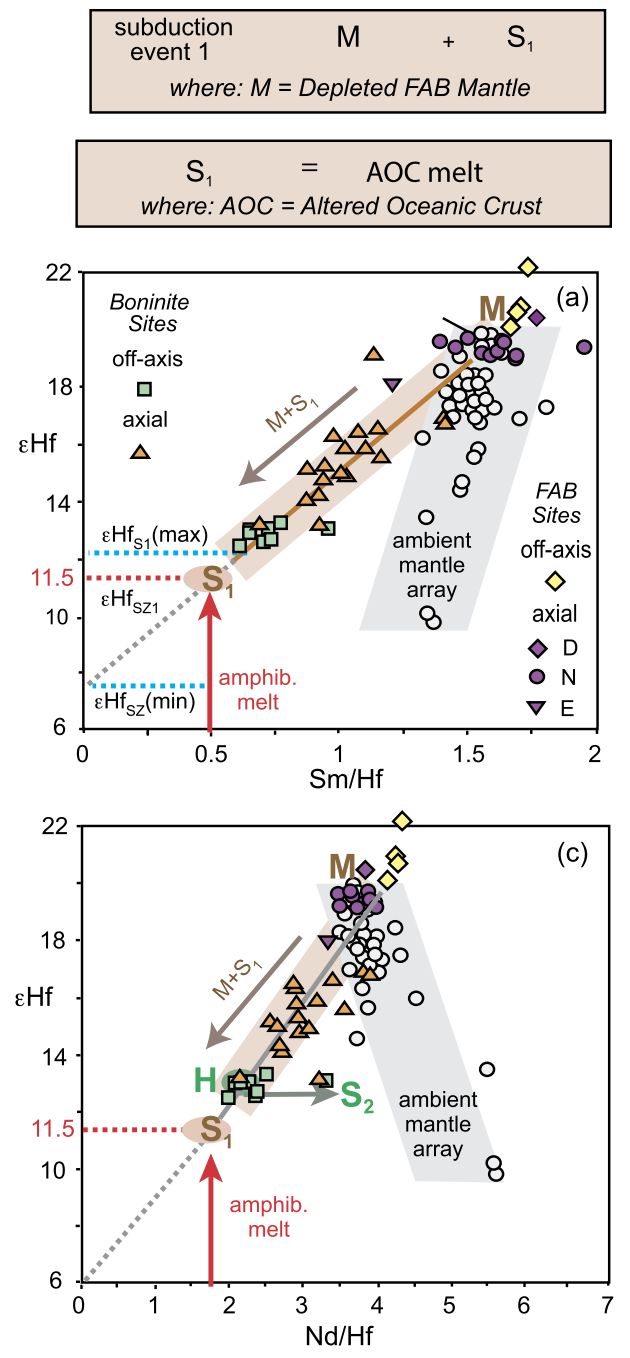

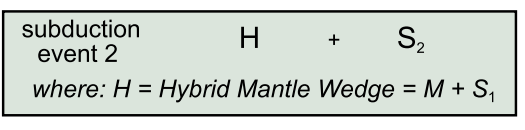
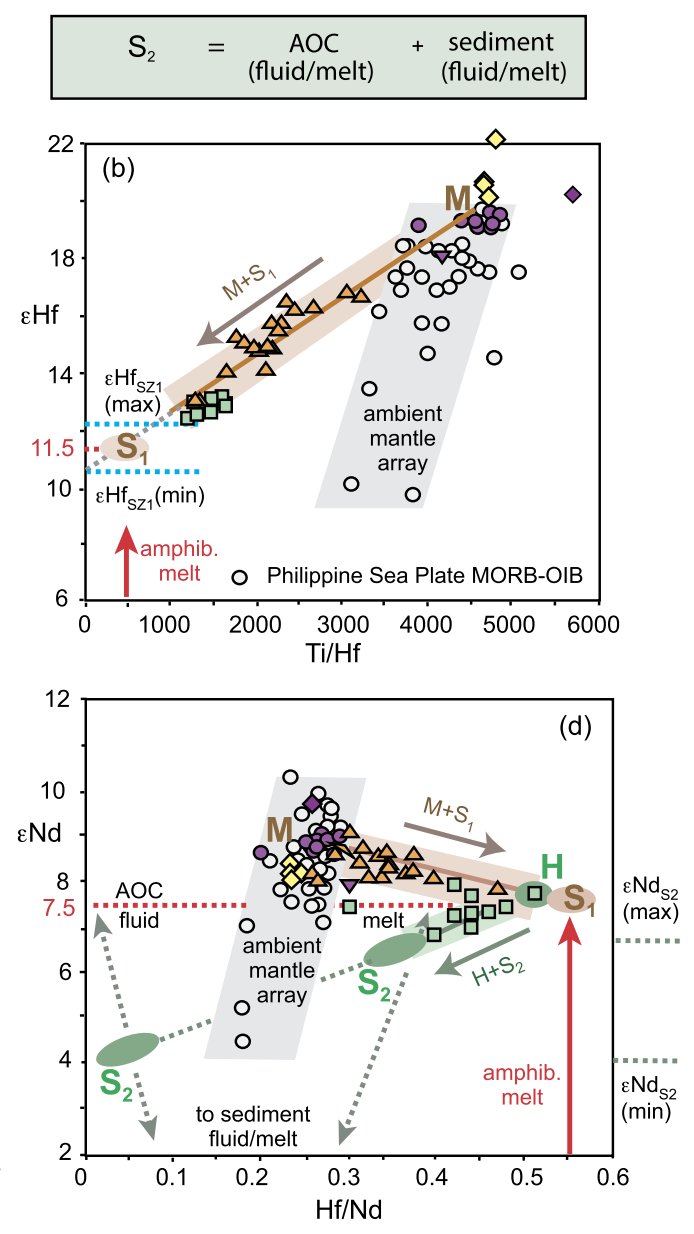

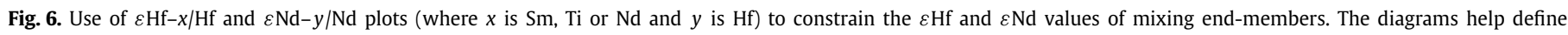

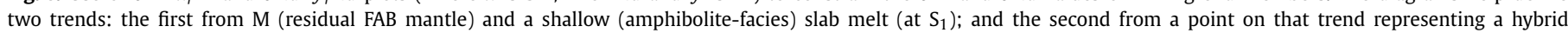

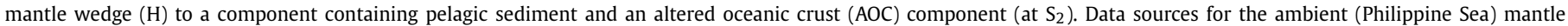

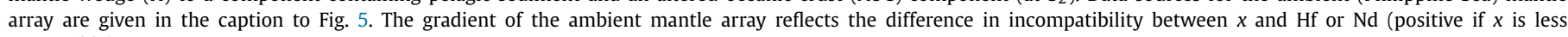
compatible).

source (Fig. 3) but, importantly, it is isotopically similar. We term this end-member 'Residual FAB Mantle' ( $M$ in Figs. 6-9).

During subduction in most active present-day arcs, $\mathrm{Sm}$ is more mobile than Hf. In consequence, arc lavas typically lie within, or adjacent to, the high $\mathrm{Sm} / \mathrm{Hf}$ (or $\mathrm{Sm} / \mathrm{Zr}$ ) side of any MORB array (e.g. Hickey-Vargas, 1989; Barry et al., 2006). In contrast, samples from the boninite sites plot towards lower Sm/Hf, reflecting their positive Hf anomalies. They have been interpreted as reflecting an amphibolite-facies slab-melt component in which $\mathrm{Sm}$ is retained by amphibole, while the slab-top temperature is high enough to dissolve sufficient zircon in the slab-derived melt to release significant concentrations of Hf (Pearce et al., 1992; Tollstrup et al., 2010; Li et al., 2013).

The $\varepsilon$ Hf value of the first subduction component $\left(\mathrm{S}_{1}\right)$ must lie on an extension of the axial-boninite trend. The minimum $\varepsilon \mathrm{Hf}$ value of the subduction component (c. 8) is the intersection with the $\mathrm{Sm} / \mathrm{Hf}$ axis - the value at which $\mathrm{Sm}$ in $\mathrm{S}_{1}$ is negligible. The maximum value (c. 12) is the lowest $\varepsilon \mathrm{Hf}$ sample of the boninite trend - the value at which mantle contribution is negligible. This places the $\varepsilon$ Hf value of $S_{1}$ between c. 8 and c. 12. This range may further be constrained using the less subduction-mobile (though more compatible) element, Ti, in place of Sm (Fig. 6b). This in- creases the minimum $\varepsilon \mathrm{Hf}$ value to c. 10.7, the value at which $\mathrm{Ti} / \mathrm{Hf}$ in $S_{1}$ is negligible.

The location and origin of $S_{1}$ can be further constrained using experimental data and slab fusion modeling. $\mathrm{Zr} / \mathrm{Sm}$ ratios have been studied in particular detail for amphibolite melting (Pearce et al., 1992; Foley et al., 2002; Foley, 2008) based on published, experimentally-derived phase proportions and partition coefficients, and taking into account minor phase solubility. Because $\mathrm{Zr} / \mathrm{Hf}$ is not significantly fractionated during the experiments, these values convert simply to $\mathrm{Sm} / \mathrm{Hf}(\mathrm{Sm} / \mathrm{Hf}=\mathrm{c}$. $35 /(\mathrm{Zr} / \mathrm{Sm}))$. Our best estimate for the average $\mathrm{Sm} / \mathrm{Hf}$ in a shallow slab melt is 0.5 , which equates to a $\varepsilon H f$ value for $S_{1}$ of 11.5 (Fig. 6a). Pearce et al. (1992: Fig. A2) obtain this ratio at c. $900{ }^{\circ} \mathrm{C}$ for water-deficient melting and c. $950{ }^{\circ} \mathrm{C}$ for water-saturated melting.

Foley's $(2002,2008)$ models report these ratios as a function of degree of melting rather than temperature, reaching $\mathrm{Sm} / \mathrm{Hf}=0.5$ after c. $5 \%$ batch melting. In both cases, reducing temperature (decreasing zircon solubility) increases $\mathrm{Sm} / \mathrm{Hf}$ (decreases $\mathrm{Zr} / \mathrm{Sm}$ ), and hence increases our $\varepsilon \mathrm{Hf}$ estimate for the slab melt. Similarly, increasing temperature decreases $\mathrm{Sm} / \mathrm{Hf}$ and the estimated $\varepsilon \mathrm{Hf}$. An error bar of \pm 0.5 epsilon units covers the range of $800-1000^{\circ} \mathrm{C}$ and $1-10 \%$ batch melting. Foley's mean values for eclogite melting equate to $\mathrm{Sm} / \mathrm{Hf}$ of 0.6 (rutile-free) to 1 (rutile-bearing), while 

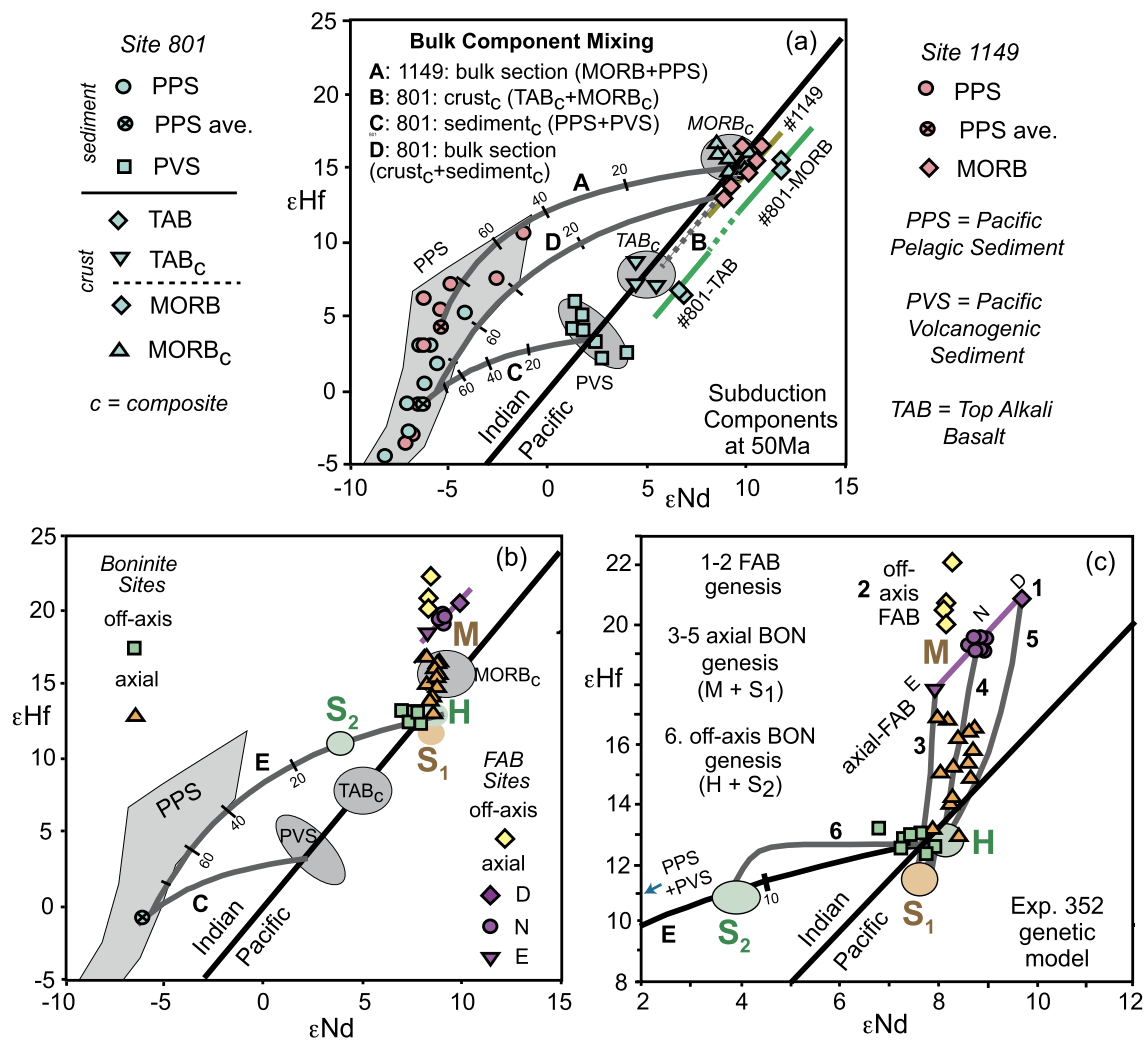

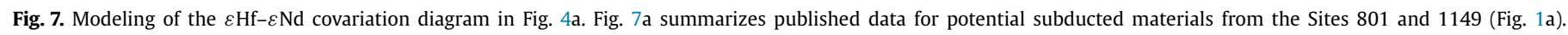

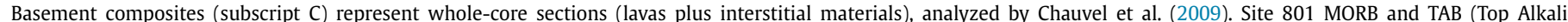

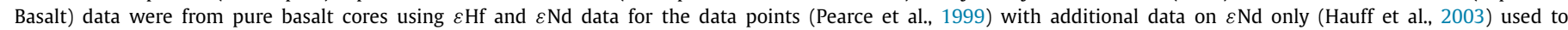

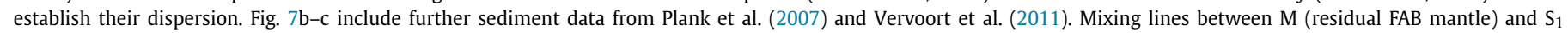
(subduction component 1 ) and between $\mathrm{H}$ (hybrid mantle wedge) and $\mathrm{S}_{2}$ (subduction component 2) constrain the compositions of bulk subducted materials.

Rapp et al. (1999, 2003) obtain Sm/Hf of 0.64 in one experimental charge (AB-1) for $3.8 \mathrm{GPa}$ and $1100^{\circ} \mathrm{C}$. These values lie above the empirical upper bound for $\varepsilon \mathrm{Hf}$, therefore making deep (eclogite facies) slab melts less likely than shallow (amphibolite facies) slab melts as the source of $S_{1}$.

The same approach gives a best estimate for amphibolite melts of c. 500 for Ti/Hf (Fig. 6b), thus supporting our $\varepsilon \mathrm{Hf}$ estimate for the $S_{1}$ end-member. In contrast, Rapp's (1999) eclogite facies melting experiment gives a $\mathrm{Ti} / \mathrm{Hf}$ ratio 1100 , too high for eclogite facies slab melts to be a likely source for $S_{1}$.

In Fig. $6 c, x=\mathrm{Nd}$, allowing us to determine the $\mathrm{Hf} / \mathrm{Nd}$ component ratios needed for the modeling of the $\varepsilon \mathrm{Hf}-\varepsilon \mathrm{Nd}$ diagram. Most of the axial-FAB samples, including D-FAB, plot in the upper part of the ambient mantle array, at $\mathrm{Nd} / \mathrm{Hf}=$ c. 3.6 and $\varepsilon \mathrm{Hf}=19.0$. The off-axis FAB are distinct in having slightly higher $\mathrm{Nd} / \mathrm{Hf}$ of 4.5 and higher $\varepsilon \mathrm{Hf}$ of c. 21.0. The value of 11.5 for $\varepsilon \mathrm{Hf}$ in the slab component from Fig. 6a-b gives Nd/Hf of 1.8 .

The inverse ratio, $\mathrm{Hf} / \mathrm{Nd}$, can then be used to delimit the $\varepsilon \mathrm{Nd}$ value for the subduction component (Fig. 6d). The axial-boninites form a trend from residual FAB mantle (M) to higher Hf/Nd. Taking the crustal end member as 0.55 (the reciprocal of $\mathrm{Nd} / \mathrm{Hf}=1.8$ from Fig. $6 \mathrm{c}$ ) then gives $\varepsilon \mathrm{Nd}=7.5$ for the slab melt component, $\mathrm{S}_{1}$.

Importantly, Fig. $6 \mathrm{~d}$ also defines better the composition of the components forming the off-axis boninites. The high $\mathrm{Hf} / \mathrm{Nd}$ endmember of the off-axis boninite trend lies within and at the lower end of the axial-boninite $\mathrm{M}-\mathrm{S}_{1}$ trend. We interpret this endmember as a mixture of slab melt and depleted mantle, which we term hybrid mantle wedge $(\mathrm{H})$. The off-axis boninites extend from $\mathrm{H}$ towards an $\mathrm{S}_{2}$ component at lower $\mathrm{Hf} / \mathrm{Nd}$. A projection of this trend intersects the $\varepsilon \mathrm{Nd}$ axis at a value of 4 for $\mathrm{Hf} / \mathrm{Nd}=0$, making this the minimum value of $\varepsilon \mathrm{Nd}$ for this component. The maximum value, the lowest analyzed $\varepsilon \mathrm{Nd}$ on the trend, is 6.5 .
Fig. $6 \mathrm{~d}$ also highlights the fact that the compositions of pelagic sediments $(\varepsilon \mathrm{Nd}=-2$ to -9$)$ lie well below the $\mathrm{H}-\mathrm{S}_{2}$ trend. This requires that the second subduction component $\left(\mathrm{S}_{2}\right)$ also includes a high $\varepsilon \mathrm{Nd}$ component and this is most likely an altered ocean crust (AOC) component. However, its $\varepsilon \mathrm{Nd}$ value is poorly defined on this projection. If it is as low at 4 , the AOC contribution must have a very low $\mathrm{Hf} / \mathrm{Nd}$ ratio, which more typical of aqueous fluid. In contrast, if it is as high as 6.5, it must have high $\mathrm{Hf} / \mathrm{Nd}$, which is more characteristic of a higher temperature slab melt or supercritical fluid.

\subsection{Characterizing the subduction component using $\varepsilon H f-\varepsilon N d$ covariations}

Two drill sites outboard of the IBM system (ODP Sites 801 and 1149: Fig. 1a) provide the most complete isotope and element data set available for the (Jurassic) crust and sediment of subducting Pacific plate and hence for interpreting the boninite site subduction components (Fig. 7a).

At Site 1149, the section comprises a Pacific-MORB basement overlain by pelagic sediments, the latter divided into a series of sedimentary sub-types (e.g. Plank et al., 2007; Chauvel et al., 2009; Vervoort et al., 2011). Site 801 is more complex. Its oceanic crust basement comprises MORB overlain by a relatively thin unit of OIB (termed 'Top Alkali Basalts', or TAB) (Hauff et al., 2003). The pure basalt compositions form an ambient mantle trend well within the 'Pacific' field in Fig. 7a. However, the composites, made up of interstitial materials in addition to lavas, are displaced to lower $\varepsilon \mathrm{Nd}$ and plot close to the Indian-Pacific boundary. In addition to pelagic sediments, the Site 801 sedimentary section contains volcanogenic sediments resulting from Jurassic intraplate magmatism. Plotted on Fig. 7a are a series of component mixing hyperbolae for Sites 1149 

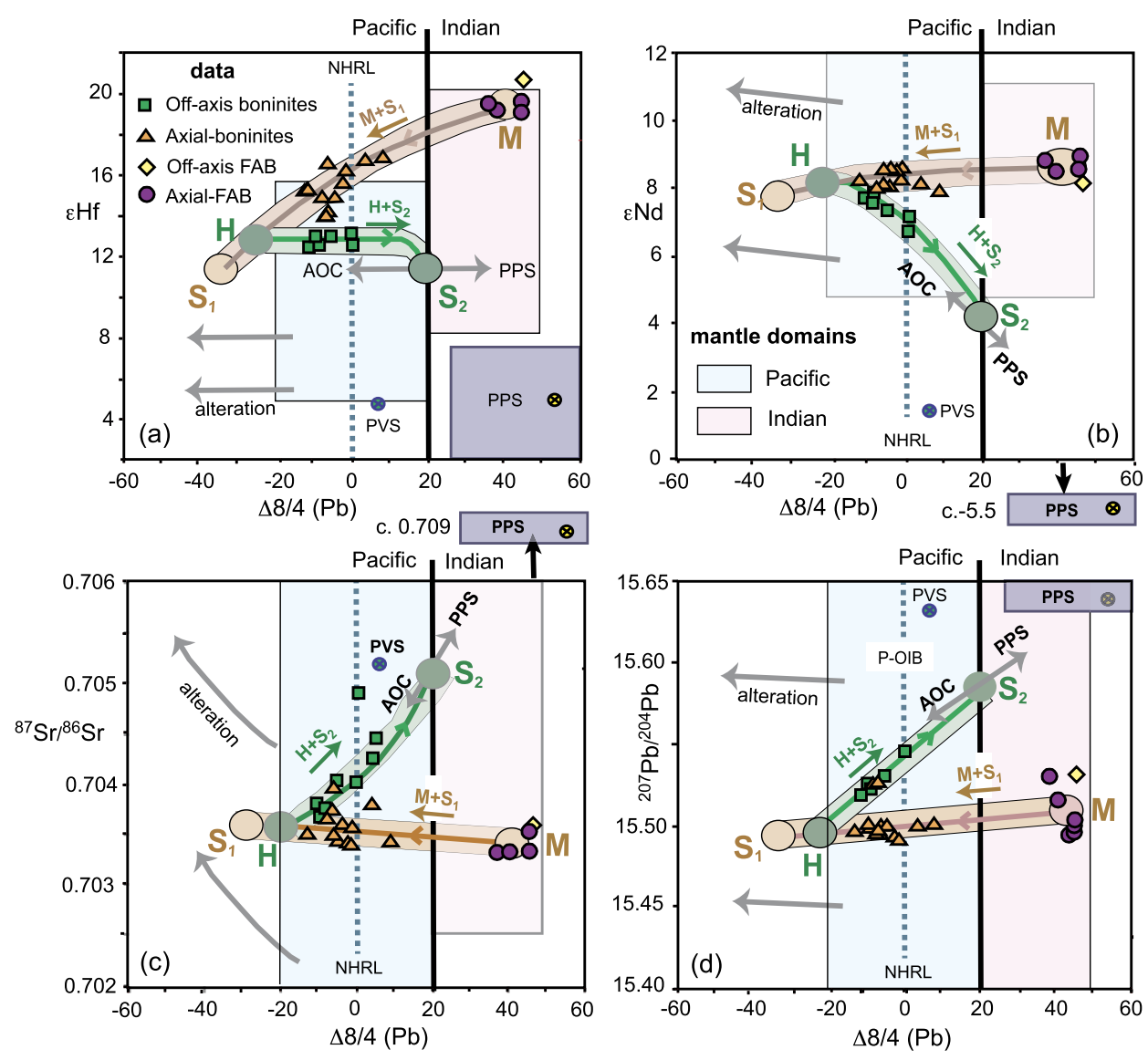

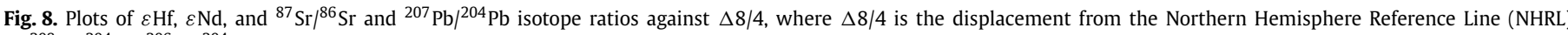

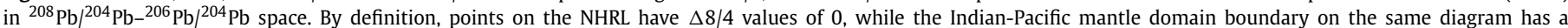

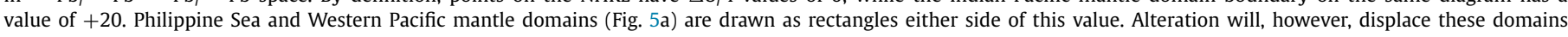

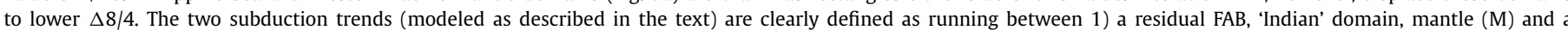

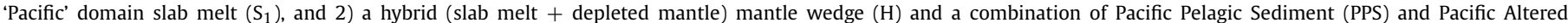
Oceanic Crust $(\mathrm{AOC})$ fluid or melt $\left(\mathrm{S}_{2}\right)$. $\varepsilon \mathrm{Hf}$ and $\varepsilon \mathrm{Nd}$ values of $\mathrm{S}_{1}$ and $\mathrm{S}_{2}$ are constrained by Fig. 5 and used in turn to constrain the Pb and $\mathrm{Sr}$ end-member compositions.

and 801 based on these published compositions. Bulk subducted compositions for Sites 1149 and 801 should plot on the bulk crust - bulk sediment curves A and D respectively.

In Fig. 7b, we plot the Exp. 352 data together with the subduction components $S_{1}$ and $S_{2}$ inferred from Fig. 6 . The obvious interpretation is that component $S_{1}$ lies between Site 801 MORB and TAB composites (i.e. along trend B on Fig. 7a). Component $S_{2}$ lies on the trend from the inferred hybrid mantle wedge $(\mathrm{H})$ and subducted Site 801 sediment (pelagic + volcanogenic). A model based on the Site 801 section can therefore explain the components produced at the start of subduction. However, for the Site 1149 section to represent these components, its Pacific MORB basement would need to be less radiogenic or some Top Alkali Basalt would also need to be present.

Fig. 7c focuses on mixing models for $\mathrm{M}-\mathrm{S}_{1}$ and $\mathrm{H}-\mathrm{S}_{2}$. The former has been constructed using a standard mixing equation with $\mathrm{Nd} / \mathrm{Hf}$ ratios obtained from the $\varepsilon \mathrm{Hf}-\mathrm{Nd} / \mathrm{Hf}$ and $\varepsilon \mathrm{Nd}-\mathrm{Hf} / \mathrm{Nd}$ plots (Pearce et al., 1999). We use axial-FAB to define the isotopic composition of residual FAB mantle (M), as in Fig. 6.

Mantle: E-FAB source (for trend 3): $\varepsilon \mathrm{Nd}_{\mathrm{M}}=7.8 ; \varepsilon \mathrm{Hf}_{\mathrm{M}}=18$; $\mathrm{Nd} / \mathrm{Hf})_{\mathrm{M}}=4.3$.

Mantle N-FAB source (for trend 4): $\varepsilon \mathrm{Nd}_{\mathrm{M}}=8.8 ; \varepsilon \mathrm{Hf}_{\mathrm{M}}=19.5$; $\mathrm{Nd} / \mathrm{Hf})_{\mathrm{M}}=3.6$.

Mantle: D-FAB source (for trend 5): $\varepsilon \mathrm{Nd}_{M}=9.7 ; \varepsilon \mathrm{Hf}_{\mathrm{M}}=21$; $\mathrm{Nd} / \mathrm{Hf})_{\mathrm{M}}=3.8$.

Subduction component $\left(\mathrm{S}_{1}=\right.$ 'Pacific' slab melt): $\varepsilon \mathrm{Nd}_{\mathrm{S} 1}=7.5$; $\left.\varepsilon \mathrm{Hf})_{\mathrm{S} 1}=11.5 ; \mathrm{Nd} / \mathrm{Hf}\right)_{\mathrm{S} 1}=1.8$.
It is apparent from resulting mixing hyperbolae (Fig. 7c, trends 3-5) that the trends from axial-FAB to $S_{1}$ encompass almost all of the axial-boninite data, so supporting the concept that the axialboninites are the product of mixing of 'Pacific' crustal slab melt and the ambient 'Indian' mantle source. To annotate the hyperbolae in terms of mass fractions of subduction zone components requires a knowledge not just of ratios but also of the absolute values of $\left.\mathrm{Nd})_{M} / \mathrm{Nd}\right)_{S 1}$ or $\left.\left.\mathrm{Hf}\right)_{M} / \mathrm{Hf}\right)_{S 1}$. Because these are not well constrained, we plot mixing lines as hyperbolae for the particular optimum value of $r$, where $r=(\mathrm{Nd} / \mathrm{Hf})_{\mathrm{M}} /(\mathrm{Nd} / \mathrm{Hf})_{\mathrm{S} 1}$. For example, the value of $r$ for Trend 4 is then 3.6/1.8=2.0.

Note that it is very rare to be able to define mantle-slab melt mixture so clearly; it is only possible here because of the distinction between 'Indian' provenance mantle and 'Pacific' provenance crust and the absence of a large sediment component. Most Western Pacific arcs are cooler and mixing lines run between 'Indian' mantle and pelagic sediment. Notable exceptions are in the reararc volcanoes (e.g. Tollstrup et al., 2010), which lie above deeper, and hence hotter, slabs.

To model the off-axis boninite variations, we continue to infer that they involve the mixing of mantle already containing the slab melt component (the hybrid mantle wedge, $\mathrm{H}$ ) and an added subduction component $\left(\mathrm{S}_{2}\right)$ with lower $\varepsilon \mathrm{Nd}$ made up of a mixture of a sediment-derived component and an AOC-derived component. Here, we base our model on the lower temperature $S_{2}$ end-member from the $\mathrm{H}-\mathrm{S}_{2}$ trend in Fig. 6d, made up of an AOC component with $\mathrm{Hf} / \mathrm{Nd}=$ c. 0 and a pelagic sediment component with $\mathrm{Hf} / \mathrm{Nd}=$ c. 0.5 . Values used are: 
Hybrid (slab melt-modified) residual mantle $(\mathrm{H}): \varepsilon \mathrm{Nd}_{\mathrm{H}}=8.0$; $\left.\varepsilon \mathrm{Hf}_{\mathrm{H}}=13 ; \mathrm{Nd} / \mathrm{Hf}\right)_{\mathrm{H}}=1.8$.

Additional subduction component $\left(\mathrm{S}_{2}\right): \varepsilon \mathrm{Nd}_{\mathrm{S} 2}=4.0 ; \varepsilon \mathrm{Hf}_{\mathrm{S} 2}=$ $11 ; \mathrm{Nd} / \mathrm{Hf})_{\mathrm{S} 2}=20$.

In fact, Fig. $6 \mathrm{~d}$ showed that this $\mathrm{S}_{2}$ could have $\varepsilon \mathrm{Nd}$ as high as 6.5 , although this higher value would have little effect on the general interpretation. We can, however, constrain this component further by incorporating isotopes of $\mathrm{Pb}$ and $\mathrm{Sr}$, which partition more readily than $\mathrm{Nd}$ and $\mathrm{Hf}$ into crust-derived fluids and sedimentderived fluids and melts (Fig. 8).

\subsection{Identifying and tracing subduction sources during subduction initiation using plots of isotope ratios $v \Delta 8 / 4$}

In Fig. 8, we plot $\varepsilon \mathrm{Hf}, \varepsilon \mathrm{Nd},{ }^{87} \mathrm{Sr} /{ }^{86} \mathrm{Sr}$ and ${ }^{207} \mathrm{~Pb} / 204 \mathrm{~Pb}$ against $\Delta 8 / 4$, where $\Delta 8 / 4$ is the orthogonal deviation from the Northern Hemisphere Reference Line (NHRL) in ${ }^{208} \mathrm{~Pb} /{ }^{204} \mathrm{~Pb}-{ }^{206} \mathrm{~Pb} /{ }^{204} \mathrm{~Pb}$ space, as defined by Hart (1984) (Fig. 4d). In all the plots, we can recognize the two subduction components that were apparent in the Hf-Nd projections. For the purpose of this paper (the tracing of mantle and subduction components following subduction initiation), we continue to interpret these trends in terms of simple mixing of two end members, but realize that this is an approximation given the complex nature of the mantle wedge.

The first trend, as modeled in Fig. 7, marks the addition of 'Pacific' slab melt $\left(\mathrm{S}_{1}\right)$ to 'Indian' Residual FAB Mantle (M). Given that the $\varepsilon \mathrm{Nd}$ value of this component was established at c. 7.5 , we can use Fig. $8 \mathrm{~b}$ to fix the $S_{1}$ component at $\Delta 8 / 4=$ c. -30 , i.e. in the expected field of Pacific altered oceanic crust (AOC).

The second trend runs from the hybrid mantle wedge $(H)$ to $\mathrm{S}_{2}$. $\mathrm{S}_{2}$ cannot be precisely defined, but constraints are sufficient to demonstrate that AOC and pelagic sediments are its principal contributors. First, an extrapolation of the linear regression in Fig. $8 \mathrm{~d}$ places $S_{2}$ on a line between $\mathrm{H}$ and the pelagic sediment field. As we inferred from Fig. $6 \mathrm{~d}$ that the $\varepsilon \mathrm{Nd}$ of $\mathrm{S}_{2}$ lies between 4 and 6.5, this in turn ties $\Delta 8 / 4$ to a value between c. 5 and 20 , some way from being pure pelagic sediment. Thus, $S_{2}$ requires a combination of AOC and Pacific pelagic sediment (PPS), possibly with some volcanogenic sediment. The former could have the same isotopic composition as $S_{1}$ if it was derived from the same subducted basalt as that supplying the slab melt for the axial-boninites. Changing the $\varepsilon \mathrm{Nd}$ value of $\mathrm{S}_{2}$ changes the ratio of these components but not the nature and composition of the end-members.

The elemental concentrations of $\mathrm{Nd}, \mathrm{Hf}$ and $\mathrm{Sr}$ relative to $\mathrm{Pb}$ in $S_{1}$ and $S_{2}$ may be gleaned from the curvatures of the axial and off-axis boninite trends respectively. These shapes of the mixing hyperbolae are a function of the ratios $r_{1}\left[(x / \mathrm{Pb})_{\mathrm{M}} /(x / \mathrm{Pb})_{S 1}\right]$ and $r_{2}\left[(x / \mathrm{Pb})_{\mathrm{H}} /(x / \mathrm{Pb})_{\mathrm{S} 2}\right]$ where $x=\mathrm{Hf}$, Nd or $\mathrm{Sr}$. These shapes match the patterns in Fig. 3, by indicating that $\mathrm{S}_{1}$ contains high $\mathrm{Pb}$ and $\mathrm{Sr}$, significant $\mathrm{Hf}$ and relatively little $\mathrm{Nd}$ and that $\mathrm{S}_{2}$ carries further $\mathrm{Pb}$ and $\mathrm{Sr}$ but undetectable $\mathrm{Hf}$ and significant $\mathrm{Nd}$. As already discussed, $S_{1}$ can be explained by residual amphibole during slab melting, $S_{2}$ by the incoming of pelagic sediment.

\section{Discussion: isotopic constraints on magma genesis following subduction initiation}

Fig. 9 presents a conceptual model that we believe best satisfies the isotopic constraints derived from this study. Further details and discussion of this model are given below.

\subsection{Constraints from the absence of a subduction component in the axial fore-arc basalts (Sites U1440 and U1441)}

The FAB drilled at IODP Exp. 352 Sites U1440 and U1441 show no clear isotopic evidence for a subduction component. There are therefore two principal modes of origin: spreading immediately after subduction; or spreading immediately before subduction. Both models are consistent with the 'Indian' character of the ambient mantle given that the position of the 'Pacific-Indian' mantle domain boundary lay outboard of the transform plate boundary (Miyazaki et al., 2015) and would have been sampled in either case. Based on regional-scale sampling, however, Reagan et al. (2010) find that subduction-free FAB similar to that drilled during Exp. 352 comprises one end-member of a spectrum that extends to FAB with clear subduction enrichment. From this, they conclude that spreading following subduction was the more likely, i.e. that extension was due to slab roll-back as proposed by Stern and Bloomer (1992). In that case, rapid mantle upwelling relative to the rate of heating of the slab is required to minimize the subduction input of the subduction-free end-member compositions.

\subsection{Constraints from the shallow slab-melting component in the axial-boninites (Holes U1439C and U1442A)}

The isotopic evidence presented here supports a model in which the axial-boninite sources are the products of variable interaction between ambient, 'Indian' domain, residual FAB mantle and shallow, amphibolite facies, slab melts $\left(\mathrm{S}_{1}\right)$. These shallow slab melts are likely tonalitic in composition, lacking the depletion in heavy REE relative to middle REE of deeper (adakitic) slab melts. This model is similar to that developed for boninites in the Bonin Ridge and its northward extension (Pearce et al., 1992; Li et al., 2013). However, our boninites from Exp. 352 are older than the Bonin Ridge boninites (c. $51 \mathrm{Ma}$ versus c. $46 \mathrm{Ma}$ ), so providing the first evidence that shallow slab melting started very soon after subduction initiation before continuing for at least 5 m.y. Early slab melting is consistent with thermal models, where the first crust to subduct melts at shallow depths because it encounters mantle uncooled by subsequent subduction (Pearce et al., 1992).

An alternative model that can be ruled out is the basalt melt contributing to $S_{1}$ was not the product of slab melting, but instead was derived from fusion of basalt (FAB) veins within the mantle wedge (Pearce et al., 1999). This model was put forward to explain the genesis of ODP Leg 125 boninites, where both end-members of the equivalent $M-S_{1}$ trend lie within the 'Indian domain'. In this study, $S_{1}$ has a clear 'Pacific' provenance, so strongly supporting the slab-melt model.

It is significant that our new data effectively rule out two previous models for the origin of the slab melts. Casey and Dewey's (1984) model of a leaky transform fault attributes slab melting to subduction of ridges within the transform zone. If true, the spreading ridges would need to lie within the 'Pacific' mantle domain. However, isotopic studies of accreted basalts show that the Izanagi-Pacific Ridge had crossed a static 'Indian-Pacific' mantle domain boundary by 80 m.y. (Miyazaki et al., 2015) and thus that the present boundary lies beneath the Pacific plate. In fact, Straub et al. (2015) found that oceanic crust of 'Indian' provenance did become the source of subduction components within the Izu-Bonin system, but not until at least 10 m.y. after subduction initiation. The same arguments negate the likelihood of larger-scale ridge subduction events being the cause of boninite magmatism (Seton et al., 2015).

\subsection{Start of sediment input and the origin of the off-axis boninites (Holes U1439C and U1442A Upper lava Units)}

A key question arising from Section 5 is why sediment input begins between the eruption of axial-boninites and the eruption of off-axis boninites. There are at least three possibilities: 1) a sediment component is also present in $S_{1}$ but is swamped by 


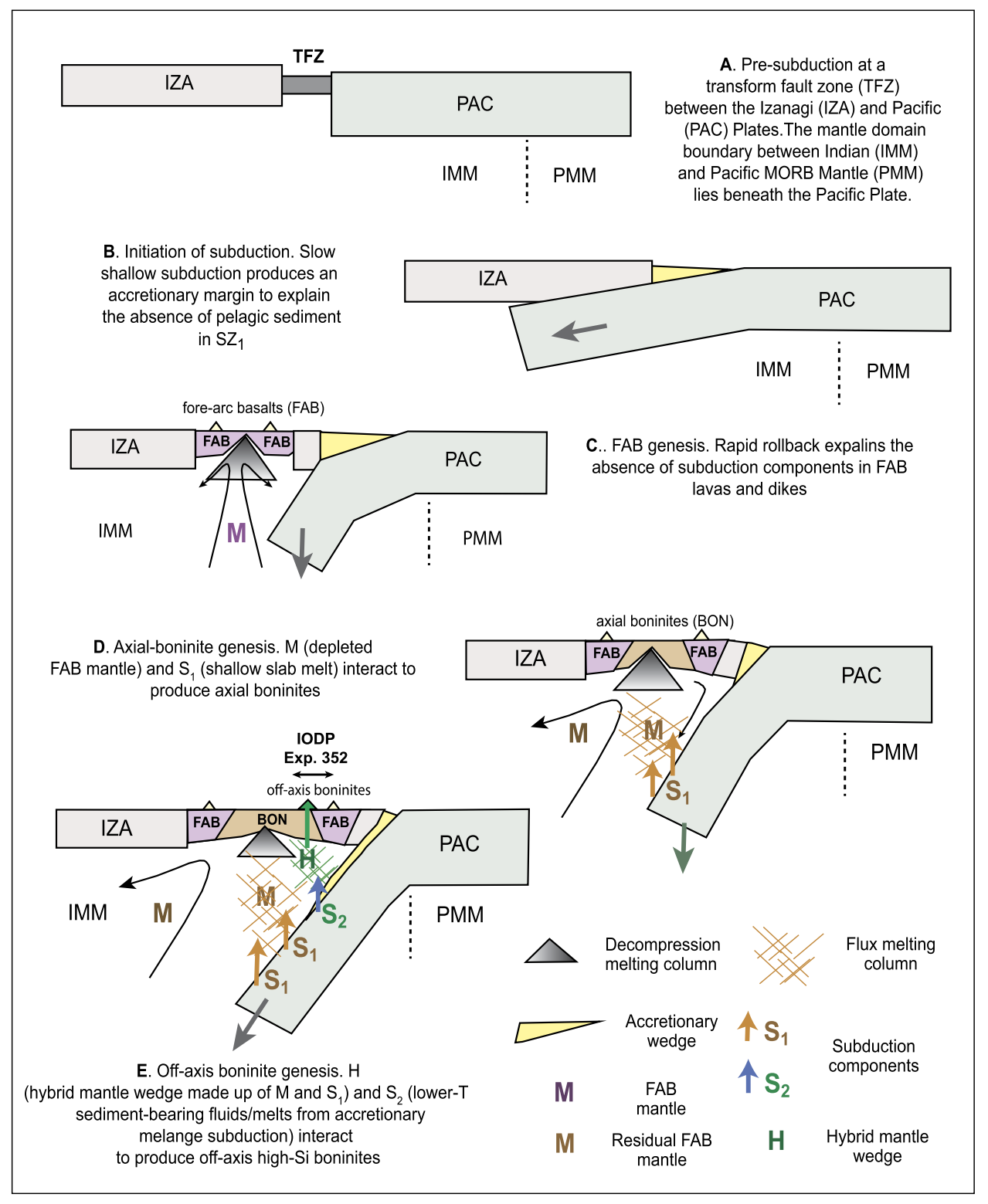

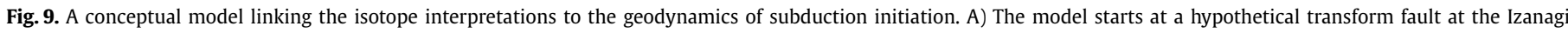

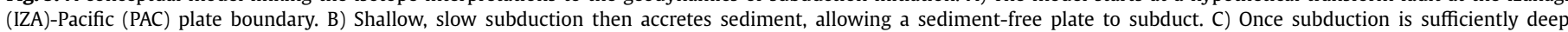

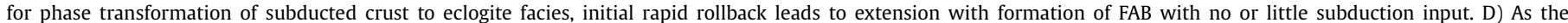

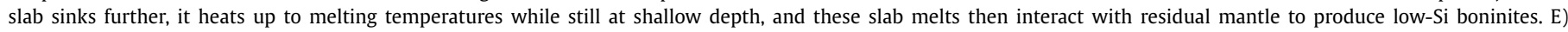

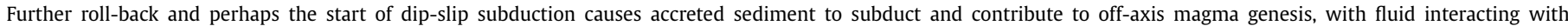

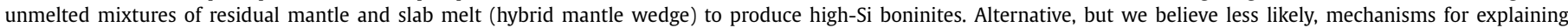

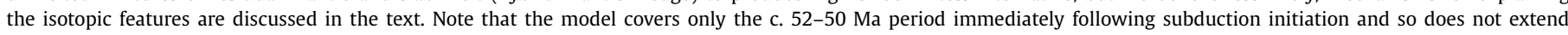

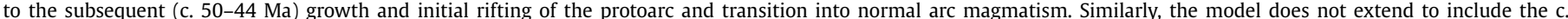

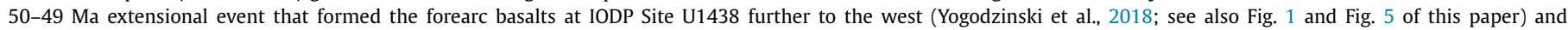
which significantly post-dates the forearc basalt spreading event depicted in Fig. 9C (Reagan et al., 2019). IMM and PMM = Indian/Pacific MORB Mantle.

the slab melt signal; 2) the first subducted crust originated in a transform zone where deeper sea-floor, less high-temperature hydrothermal activity and more detachment faulting resulted in minimal sedimentary cover; and 3) the sediment is initially accreted rather than subducted. The argument against first option is that $\mathrm{Pb}$ isotopes proved highly sensitive to the sediment content of $S_{2}$, and so would have detected a sediment component in $S_{1}$ were it present in significant proportion. The second option cannot be ruled out, but transform faults are rarely sediment-free and often contain debris flows made up of igneous clasts in sediment matrices, which would contribute a sedimentary signal to the subduction component. Thus, we consider the accretionary option to be most likely.
In the accretionary model, sediments would have to be accreted at the start of subduction so that the slab that initially rolls back is sediment free. For this to happen, subduction dynamics must change between the input of $S_{1}$ and $S_{2}$ in a way that first inhibits sediment subduction and then permits it. Critical taper theory (e.g. Dahlen, 1990) supported by subduction zone comparisons (Clift and Vannucchi, 2004) reveal that shallow and slow subduction favor development of accretionary margins and hence off-scraping of sediment, while steep and fast subduction favor non-accretionary margins and hence sediment subduction.

In Fig. 9(A) subduction starts slowly and at a shallow angle up to the point at which oceanic crust converts to eclogite, after which (B) rapid roll-back takes place of the sediment-free sub- 
ducting slab culminating in addition of $S_{1}$, followed by (C) normal, rapid and steep subduction (likely with a roll-back component) in which the accreted sediment is able to subduct. Introduction of fluid and/or melt from sediment and $\mathrm{AOC}\left(\mathrm{S}_{2}\right)$, either separately or together as a mélange with altered basaltic debris (Nielsen and Marschall, 2017), then allows the sub-solidus hybrid mantle wedge to undergo the additional hydration to produce the off-axis boninites trench-side of the original ridge.

\section{Conclusions}

1. The first stage of magmatism following subduction initiation is associated with sea-floor spreading following subduction initiation and results in the eruption of forearc basalts (FAB) at IODP Sites U1440 and U1441. Isotope data confirm that these FAB lack a subduction component and so can be used to characterize the ambient mantle reservoir prior to the input of the subduction component. Notably, this reservoir had 'Indian' provenance and had experienced an ancient (possibly Palaeozoic), garnet facies depletion event, similar to that proposed by Yogodzinski et al. (2018) based on the slightly younger, and more trench-distal, basalts drilled at IODP Site U1438.

2. The first evidence of subduction is recorded by the axial boninites at IODP Sites U1439 and U1442. Their isotopic compositions follow mixing trends between residual mantle of 'Indian' provenance and oceanic crust of 'Pacific' provenance. The latter had undergone shallow (amphibolite facies) fusion to give positive $\mathrm{Hf}$ anomalies on extended REE plots, so providing further evidence for slab fusion at the start of subduction. The absence of sediment in the isotope signal may be explained by initial sediment accretion, although other options are possible.

3. The final stage is the eruption of the off-axis boninites. Their isotopic compositions follow mixing trends between a hybrid mantle wedge similar to the axial boninite source (slab melt plus residual mantle) and a subduction component derived from altered oceanic crust (AOC) and Pacific pelagic sediment (PPS). Our favored explanation for the sudden appearance of the sediment component is subduction of previously accreted material resulting from increased subduction rate and slab dip. As this event takes place $<2$ m.y. after the genesis of the forearc basalts (Reagan et al., 2019), the results provide evidence that subduction initiation was followed by a rapidly evolving system in terms of geodynamics, magma genesis and crustal accretion.

\section{Acknowledgements}

We thank the International Ocean Discovery Program (IODP) for samples and infrastructure. We appreciate the contributions of the Staff Scientist (K. Petronotis) and remaining members of the IODP Exp. 352 Scientific Party as well as the officers and crew, and scientific support staff, on the JOIDES Resolution. We thank Gene Yogodzinski and an anonymous referee for their helpful recommendations and Tamsin Mather for her editorial support. HongYan Li additionally thanks the Strategic Priority Research Program of the Chinese Academy of Sciences (Grant No. XDB18000000) and the Chinese National Program on Global Change and AirSea Interaction (GASI-GEOGE-02). Shervais, Ryan and Reagan thank the USSSP for initial Expedition funding and the NSF for grants OCE1558689, OCR1558855 and OCE1558647 respectively. Taylor \& Pearce and Prytulak thank the NERC (UK) for grants NE/M012034/1 and NE/M010643 respectively. Godard thanks CNRS-INSU Terre Solide 'Soutien Post-campagne à la Mer'. Hong-Yan Li thanks Xiang Li, Le Zhang and Jinlong Ma for their contributions to the analyses in GIGCAS laboratories. Prytulak thanks K. Kressig, B.J. Coles, M. Mangler and F. Wei for their contributions to the analyses and running of the MAGIC laboratories. This is contribution No. IS-2640 of GIG-CAS.

\section{Appendix. Supplementary material}

Supplementary material related to this article can be found online at https://doi.org/10.1016/j.epsl.2019.04.041.

\section{References}

Barry, T., Pearce, J.A., Leat, P.T., Millar, I.L., 2006. Hf isotope evidence for selective mobility of high-field-strength-elements in a subduction setting: South Sandwich Islands. Earth Planet. Sci. Lett. 252, 223-244.

Casey, J.F., Dewey, J.F., 1984. Initiation of subduction zones along transform and accreting plate boundaries, triple-junction evolution and forearc spreading centres - implications for ophiolitic geology and obduction. Geol. Soc. (Lond.) Spec. Publ. 13, 269-290.

Chauvel, C., Marini, J.-C., Plank, T., Ludden, J., 2009. Hf-Nd input flux in the IzuMariana subduction zone and recycling of subducted material in the mantle. Geochem. Geophys. Geosyst. 10, 2008GC002101.

Clift, P., Vannucchi, P., 2004. Controls on tectonic accretion versus erosion in subduction zones: implications for the origin and recycling of the continental crust. Rev. Geophys. 42, RG2001. https://doi.org/10.1029/2003RG000127.

Cosca, M.A., Arculus, R.J., Pearce, J.A., Mitchell, J.G., 1998. ${ }^{40} \mathrm{Ar} /{ }^{39} \mathrm{Ar}$ and $\mathrm{K}-\mathrm{Ar}$ geochronological age constraints for the inception and early evolution of the Izu-Bonin arc system. Isl. Arc 7, 579-595.

Crawford, A.J. (Ed.), 1989. Boninites and Related Rocks. Unwin Hyman, London. 465 pp.

Dahlen, F.A., 1990. Critical taper model of fold-and-thrust belts and accretionary wedges. Annu. Rev. Earth Planet. Sci. 18, 55-99.

Dilek, Y., Flower, M.F.J., 2003. Arc-trench rollback and forearc accretion; 2, A model template for ophiolites in Albania, Cyprus, and Oman. Geol. Soc. Spec. Publ. 218, $43-68$.

Foley, S., 2008. A trace element perspective on Archean crust formation and on the presence or absence of Archean subduction. Spec. Pap., Geol. Soc. Am. 440, $31-50$

Foley, S., Tiepolo, M., Vannucci, R., 2002. Growth of early continental crust controlled by melting of amphibolite in subduction zones. Nature 417, 837-840.

Gale, A., Dalton, C.A., Langmuir, C.H., Su, Y., Schilling, J.-G., 2013. The mean composition of ocean ridge basalts. Geochem. Geophys. Geosyst. 14, 489-518.

Gurnis, M., Müller, R.D., Moresi, L., 1998. Cretaceous vertical motion of Australia and the Australian-Antarctic Discordance. Science 279, 1499-1504.

Hart, S.R., 1984. A large-scale isotope anomaly in the Southern Hemisphere mantle. Nature 309, 753-757.

Hauff, F., Hoernle, K., Schmidt, A., 2003. Sr-Nd-Pb composition of Mesozoic Pacific oceanic crust (Site 1149 and 801, ODP Leg 185): implications for alteration of ocean crust and the input into the Izu-Bonin-Mariana subduction system. Geochem. Geophys. Geosyst. 4, 2002GC000421.

Heydolph, K., Murphy, J., Geldmacher, J., Romanova, I.V., Greene, A., Hoernle, K., Weis, D., Mahoney, J., 2014. Plume versus plate origin for the Shatsky Rise oceanic plateau (NWPacific): insights from $\mathrm{Nd}, \mathrm{Pb}$ and $\mathrm{Hf}$ isotopes. Lithos 200-201, 49-63.

Hickey-Vargas, R., 1989. Boninites and tholeiites from DSDP Site 458, Mariana forearc. In: Crawford, A.J. (Ed.), Boninites and Related Rocks. Unwin Hyman, London, pp. 339-356.

Hickey-Vargas, R. 1998. Origin of the Indian Ocean-type isotopic signature in basalts from Philippine Sea plate spreading centers: an assessment of local versus largescale processes. J. Geophys. Res. 103, 20,963-20,979.

Hussong, D.M., Uyeda, S., 1981. Tectonic processes and the history of the Mariana arc: a synthesis of the results of Deep Sea Drilling Project Leg 60. In: Hussong, D.M., Uyeda, S., et al. (Eds.), Init. Repts. DSDP, 60. U.S. Govt. Printing Office, Washington, pp. 909-929.

Ishizuka, O., Tani, K., Reagan, M.K., Kanayama, K., Umino, S., Harigane, Y., Sakamoto, I., Miyajima, Y., Yuasa, M., Dunkley, D.J., 2011. The timescales of subduction initiation and subsequent evolution of an oceanic island arc. Earth Planet. Sci. Lett. 306, 229-240.

Ishizuka, O., Hickey-Vargas, R., Arculus, R.J., Yogodzinski, G.M., Savov, I.P., Kusanoa, Y., McCarthy, A., Brandl, P.A., Sudoi, M., 2018. Age of Izu-Bonin-Mariana arc basement. Earth Planet. Sci. Lett. 481, 80-90.

Janney, P.E., Le Roex, A.P., Carlson, R.W., 2005. Hafnium isotope and trace element constraints on the nature of mantle heterogeneity beneath the central Southwest Indian Ridge $\left(13^{\circ} \mathrm{E}\right.$ to $\left.47^{\circ} \mathrm{E}\right)$. J. Petrol. 46, 2427-2464.

Kempton, P.D., Pearce, J.A., Barry, T.L., Fitton, J.G., Langmuir, C., Christie, D.M., 2002. $\mathrm{Sr}-\mathrm{Nd}-\mathrm{Pb}-\mathrm{Hf}$ isotope results from ODP Leg 187: evidence for mantle dynamics of the Australian-Antarctic Discordance and origin of the Indian MORB source. Geochem. Geophys. Geosyst. 3, 2002 GC000320.

Leng, W., Gurnis, M., Asimow, P., 2012. From basalts to boninites; the geodynamics of volcanic expression during induced subduction initiation. Lithosphere 4, 511-523. 
Li, Y.-B., Kimura, J.-I., Machida, S., Ishii, T., Ishiwatari, S., Maruyama, S., Qiu, N.-N., Ishikawa, T., Kato, Y., Haraguchi, S., Takahata, N., Hirahara, Y., Miyazaki, T., 2013. High-Mg adakite and low-Ca boninite from a Bonin fore-arc seamount: implications for the reaction between slab melts and depleted mantle. J. Petrol. 54, 1149-1175.

Macpherson, C.G., Hall, R., 2001. Tectonic setting of Eocene boninite magmatism in the Izu-Bonin-Mariana forearc. Earth Planet. Sci. Lett. 186, 215-230.

Miyazaki, T., Kimura, J.-I., Senda, R., et al., 2015. Missing western half of the Pacific Plate: geochemical nature of the Izanagi-Pacific Ridge interaction with a stationary boundary between the Indian and Pacific mantles. Geochem. Geophys. Geosyst. 16, 3309-3332. https://doi.org/10.1002/2015GC005911.

Nielsen, S.G., Marschall, H.R., 2017. Geochemical evidence for mélange melting in global arcs. Sci. Adv. 3, e1602402.

Niu, Y., O'Hara, M.J., Pearce, J.A., 2003. Initiation of subduction zones as a consequence of lateral compositional buoyancy contrast within the lithosphere: a petrological perspective. J. Petrol. 44, 851-866.

Pearce, J.A., van der Laan, S.R., Arculus, R.J., Murton, B.J., Ishii, T., Peate, D.W., Parkinson, I., 1992. Boninite and harzburgite from Leg 125 (Bonin-Mariana Forearc): a case study of magma genesis during the initial stages of subduction. In: Proceedings of the Ocean Drilling Program Scientific Results, vol. 125, pp. 623-659.

Pearce, J.A., Kempton, P.D., Nowell, G.M., Noble, S.R., 1999. Hf-Nd element and isotope perspective on the nature and provenance of mantle and subduction components in western Pacific arc-basin systems. J. Petrol. 40, 1579-1611.

Plank, T., Kelley, K.A., Murray, R.W., Stern, L.Q., 2007. Chemical composition of sediments subducting at the Izu-Bonin trench. Geochem. Geophys. Geosyst. 8, 2006 GC001444.

Rapp, R.P., Shimizu, N., Norman, M.D., Applegate, G.S., 1999. Reaction between slabderived melts and peridotite in the mantle wedge: experimental constraints at 3.8 GPa. Chem. Geol. 160, 335-356.

Rapp, R.P., Shimizu, N., Norman, M.D., 2003. Growth of early continental crust by partial melting of eclogite. Nature 425, 605-609.

Reagan, M.K., Ishizuka, O., Stern, R.J., Kelley, K.A., Ohara, Y., Blichert-Toft, J., Bloomer, S.H., Cash, J., Fryer, P., Hanan, B., Hickey-Vargas, R., Ishii, T., Kimura, J.-I., Peate, D.W., Rowe, M.C., Woods, M., 2010. Fore-arc basalts and subduction initiation in the Izu-Bonin-Mariana system. Geochem. Geophys. Geosyst. 11, 1-17.

Reagan, M.K., Pearce, J.A., Petronotis, K.E., the Expedition 352 Scientists, 2015. Expedition 352 summary. Proc. IODP 352. https://doi.org/10.14379/iodp.proc.352. 101.2015.

Reagan, M.K., Pearce, J.A., Petronotis, K., Almeev, R.R., Avery, A.J., Carvallo, C., Chapman, T., Christeson, G.L., Ferré, E.C., Godard, M., Heaton, D.E., Kirchenbaur, M., Kurz, W., Kutterolf, S., Li, H., Li, Y., Michibayashi, K., Morgan, S., Nelson, W.R., Prytulak, J., Python, M., Robertson, A.H.F., Ryan, J.G., Sager, W.W., Sakuyama, T., Shervais, J.W., Shimizu, K., Whattam, S.A., 2017. Subduction initiation and ophiolite crust: new insights from IODP drilling. Int. Geol. Rev. 59. https:// doi.org/10.1080/00206814.2016.1276482.
Reagan, M.K., Heaton, D.E., Schmitz, M.D., Pearce, J.A., Shervais, J.W., Koppers, A.A.P., 2019. Forearc ages reveal extensive short-lived and rapid seafloor spreading following subduction initiation. Earth Planet. Sci. Lett. 506, 520-529.

Salters, V.J.M., Mallick, S., Hart, S.R., Langmuir, C.E., Stracke, A., 2011. Domains of depleted mantle: new evidence from hafnium and neodymium isotopes. Geochem. Geophys. Geosyst. 12, GC003617.

Savov, I.P., Hickey-Vargas, R., D’Antonio, M., Ryan, J.G., Spadea, P., 2006. Petrology and geochemistry of West Philippine Basin Basalts and early Palau-Kyushu arc volcanic casts from ODP Leg 195, Site 1201D: implications for the early history of the Izu-Bonin-Mariana Arc. J. Petrol. 47, 277-299.

Seton, M., Flament, N., Whittaker, J., Muller, D., Gurnis, M., Bower, D.J., 2015. Ridge subduction sparked reorganization of the Pacific plate-mantle system 60-50 million years ago. Geophys. Res. Lett. 42. https://doi.org/10.1002/2015GL063057.

Shervais, J.W., 2001. Birth, death, and resurrection: the life cycle of suprasubduction zone ophiolites. Geochem. Geophys. Geosyst. 2, 2000GC000080.

Shervais, J.W., Reagan, M.K., Haugen, E., Almeev, R.R., Pearce, J.A., Prytulak, J., Ryan, J.G., Whattam, S.A., Godard, M., Chapman, T., Li, H.-Y., Kurz, W., Nelson, W.R., Heaton, D.E., Kirchenbaur, M., Shimizu, K., Sakuyama, T., Li, Y., Vetter, S.K., 2019. Magmatic response to subduction initiation: Part 1. Fore-arc basalts of the IzuBonin arc from IODP Expedition 352. Geochem. Geophys. Geosyst. 20. https:// doi.org/10.1029/2018GC007731.

Stern, R.J., Bloomer, S.H., 1992. Subduction zone infancy; examples from the Eocene Izu-Bonin-Mariana and Jurassic California arcs. Geol. Soc. Am. Bull. 104 $1621-1636$.

Straub, S.M., Woodhead, J.D., Arculus, R.J., 2015. Temporal evolution of the Mariana Arc: mantle wedge and subducted slab controls revealed with a tephra perspective. J. Petrol. 56, 409-439. https://doi.org/10.1093/petrology/egv005.

Sun, S.S., McDonough, W.F., 1989. Chemical and isotopic systematics of oceanic basalts: implications for mantle composition and processes. Geol. Soc. (Lond.) Spec. Publ. 42, 313-346.

Tollstrup, D.L., Gill, J.B., Kent, A., Prinkey, D., Williams, R., Tamura, Y., Ishizuka, O., 2010. Across-arc geochemical trends in the Izu-Bonin arc: contributions from the subducting slab, revisited. Geochem. Geophys. Geosyst. 11, 2009 GC002847.

Vervoort, J.D., Plank, T., Prytulak, J., 2011. The Hf-Nd isotopic composition of marine sediments. Geochim. Cosmochim. Acta 75, 5903-5926.

Woodhead, J., Stern, R.J., Pearce, J., Hergt, J., Vervoort, J., 2012. Hf-Nd isotope variation in Mariana Trough basalts: the importance of "ambient mantle" in the interpretation of subduction zone magmas. Geology 40, 539-542.

Wu, W., Suppe, J., Lu, R., Kanda, R., 2016. Philippine Sea and East Asian plate tectonics since $52 \mathrm{Ma}$ constrained by new subducted slab reconstruction methods. J. Geophys. Res., Solid Earth 121, 4670-4741.

Yogodzinski, G., Bizimis, M., Hickey-Vargas, R., McCarthy, A., Hocking, B.D., Savov, I.P., Ishizuka, O., Arculus, R., 2018. Implications of Eocene-age Philippine Sea and Forearc basalts for initiation and early history of the Izu-Bonin-Mariana arc. Geochem. Cosmochim. Acta. https://doi.org/10.1016/j.gca.2018.02.047. 